\title{
An updated suprageneric classification of planktic foraminifera after growing evidence of multiple benthic-planktic transitions
}

\author{
Una clasificación supragenérica actualizada de foraminíferos planctónicos tras la evidencia creciente de \\ múltiples transiciones bentónico-planctónicas
}

Ignacio ARENILLAS (1), J. Antonio ARZ (1) \& Vicente GILABERT (1)

\begin{abstract}
Planktic foraminifera have traditionally been classified within a single order: Globigerinida. However, recent phylogenetic studies, both molecular and stratophenetic, are evidencing the polyphyletic origin of planktic foraminifera from several benthic ancestors. At least four independent events of benthic-planktic transition have been identified. One of them occurred after the Cretaceous-Paleogene boundary mass extinction, originating the first Cenozoic globigerinids. Another three occurred in the Mesozoic, originating three groups of planktic foraminifera (globotruncanids, heterohelicids and guembelitriids) not related phylogenetically to each other or to current globigerinids. These findings make it necessary to carry out an exhaustive review of their suprageneric systematics, mainly at the order level. Here we propose a new, more natural classification, grouping them into four orders: Globigerinida, Heterohelicida, Globotruncanida n. ord., and Guembelitriida n. ord. To better reflect the diversity and phylogeny of planktic foraminifera, we have also defined two new superfamilies: Abathomphaloidea $n$. superfam. and Parvularugoglobigerinoidea $\mathrm{n}$. superfam., and one new family: Parvularuglobigerinidae $n$. fam.
\end{abstract}

Resumen: Los foraminíferos planctónicos han sido tradicionalmente clasificados en un solo orden: Globigerinida. Sin embargo, estudios filogenéticos recientes, tanto moleculares como estratofenéticos, están evidenciando el origen polifilético de los foraminíferos planctónicos desde varios ancestros bentónicos. Se han identificado al menos cuatro eventos independientes de transición bentónico-planctónica. Uno de ellos ocurrió tras la extinción en masa del límite Cretácico-Paleógeno, originando los primeros globigerínidos cenozoicos. Otros tres ocurrieron en el Mesozoico, originando tres grupos de foraminíferos planctónicos (globotruncánidos, heterohelícidos y guembelítridos), los cuales no están filogenéticamente relacionados entre sí ni con los actuales globigerínidos. Estos hallazgos hacen necesario realizar una revisión exhaustiva de su sistemática supragenérica, principalmente a nivel de orden. Nosotros proponemos aquí una nueva clasificación más natural que los agrupa en cuatro órdenes: Globigerinida, Heterohelicida, Globotruncanida $\mathrm{n}$. ord. y Guembelitriida n. ord. Para reflejar mejor la diversidad y la filogenia de los foraminíferos planctónicos, hemos definido también dos nuevas superfamilias: Abathomphaloidea $n$. superfam. y Parvularugoglobigerinoidea $n$. superfam., y una nueva familia: Parvularuglobigerinidae $n$. fam.
Received: 30 July 2021

Accepted: 10 December 2021

Published online: 7 February 2022

Corresponding author:

Ignacio Arenillas

ias@unizar.es

Keywords:

Systematics

Polyphyletic origin

Phylogeny

Meroplanktic

Tychoplanktic

Palabras-clave:

Sistemática

Origen polifilético

Filogenia

Meroplanctónico

Ticoplanctónico

\section{INTRODUCTION}

In the last two decades, the systematics of planktic foraminifera have been subjected to continuous revisions. Multiple taxonomic studies are evidencing that their diversity is much greater than previously believed, and not only at the species level but also at generic and suprageneric levels (e.g., Olsson et al., 1999; Korchagin, 2003; Pearson et al., 2006; Huber \& Leckie, 2011; BouDagher-Fadel, 2012, 2015; Georgescu, 2013a, 2013b, 2015; Georgescu \& Henderson, 2014; Georgescu et al., 2014; Arenillas \& Arz, 2017; Wade et al., 2018). Planktic foraminifera have been traditionally classified according to the characteristics of their external calcareous test, both general morphology and microstructural features (Loeblich \& Tappan, 1964, 1987; Hemleben et al., 1989). However, a classification of planktic foraminifera exclusively based on morphologic characters may fail not only to determine their real diversity but also to know their origin and the true phylogenetic relationships between them. For example, after generating a pyrosequencing

(C) The Author(s) 2022. This is an open-access article distributed under the terms of the Creative Commons Attribution 4.0 International License (for details please see http://creativecommons.org/licenses/by/4.0/), which permits use, copy, adaptation, distribution, and reproduction in any medium or format, as long as you give appropriate credit to the original author(s) and the source. 
dataset of ca. 100,000 partial 18S rRNA foraminiferal sequences, Morard et al. (2018) recently discovered that, although their diversity is finite (probably a few hundred species of which just over 60 are known through morphological studies), a considerable part of current planktic foraminiferal species has its origin in unknown lineages. Nevertheless, deeper phylogenetic studies, both molecular in recent species (ribosomal DNA) and stratophenetic in fossil species (morphologyontogeny and biostratigraphy), are allowing little by little to generate a more natural classification. The discovery of new phylogenetic lineages, which arose on many occasions through processes of iterative evolution, makes it necessary to carry out an exhaustive review of the suprageneric systematics of planktic foraminifera, even at the order level.

Planktic foraminifera have traditionally been clustered into the suborder Globigerinina Lankester, 1885 (see Loeblich \& Tappan, 1964, 1987), which was elevated to order Globigerinida by Loeblich and Tappan (1992). However, the monophyletic character of the planktic foraminifera has gradually lost ground in the light of several molecular phylogenetic studies, which suggests several events of benthic-planktic transitions in their evolutionary history. For example, Darling et al. (1997, 2009), de Vargas et al. (1997) and Aurahs et al. (2009) provided new evidence after testing different hypotheses on the phylogenetic relationships of recent planktic foraminifera using ribosomal DNA sequences (SSU-rDNA). This implies that grouping all them in the order Globigerinida could be artificial. The molecular evidence is not yet conclusive, but highresolution stratophenetic studies seem to corroborate the hypothesis that, except for the guembelitriids, the Cenozoic planktic foraminifera are unrelated with those of the Mesozoic (Arenillas \& Arz, 2017). Similarly, BouDagher-Fadel $(2012,2015)$ proposed that the heterohelicids are not phylogenetically related with the order Globigerinida, and should be placed within the order Heterohelicida, which Fursenko (1958) defined to represent Cretaceous planktic foraminiferal taxa with serial arrangement (mainly biserial and multiserial, but also triserial).

In light of recent findings on polyphyletic origin of planktic foraminifera from benthic taxa, our objective is to update the classification of planktic foraminifera. For it, we propose a new order (Globotruncanida Arz, Arenillas \& Gilabert n. ord.) that groups the spiral forms of the Mesozoic, which seem to have a monophyletic origin in the Middle Jurassic. In addition, we propose another new order (Guembelitriida Arenillas, Arz \& Gilabert n. ord.), two new superfamilies (Parvularuglobigerinoidea Arenillas, Arz \& Gilabert n. superfam., and Abathomphaloidea Arz, Arenillas \& Gilabert n. superfam.) and one new family (Parvularuglobigerinidae Arenillas, Arz \& Gilabert n. fam.), and review the suprageneric categories to better reflect the diversity and phylogeny of planktic foraminifera.

\section{BACKGROUND ON PLANKTIC FORAMINI- FERAL TAXONOMY AND PHYLOGENY}

The suprageneric classification of planktic foraminifera at family and superfamily levels is based on significant characters such as the wall structure and surface or the mode of chamber addition (arrangement), although some also put emphasis upon the aperture position, the external apertural modifications or some significant test features, as the presence of tegilla, bullae, carinae or tubulospines (Loeblich \& Tappan, 1987; BouDagherFadel, 2012, 2015). Many planktic foraminiferal families have been proposed depending on whether the wall surface is smooth, pitted, cancellate, reticulate (favusellid), spinose, hispid (finely pustulate), pustulate, muricate (densely pustulate), pore-mounded (papillate, papillose), rugose, costate or striate. Based mainly on these morphological criteria, Loeblich and Tappan (1987; see supplementary text $\mathrm{S} 1$ ) systematically described benthic and planktic foraminifera at generic and suprageneric levels. These authors drew on almost all previous studies on planktic foraminiferal taxonomy, such as Subbotina $(1953,1971)$, Loeblich (1957), Luterbacher (1964), Banner and Blow (1965), Loeblich and Tappan (1964), Postuma (1971), Jenkins (1971), Smith and Pessagno (1973), Stainforth et al. (1975), Berggren (1977), Robaszynski and Caron (1979), Blow (1979), Saito et al. (1981), Banner (1982), Korchagin (1982), Kennett and Srinivasan (1983), and Robaszynski et al. (1984).

Around the same time that Loeblich and Tappan (1987) finished their foraminiferal compilation, Bolli et al. (1985) edited an extensive review of planktic foraminiferal taxonomy in various chapters, highlighting Caron (1985) for Cretaceous, Toumarkine and Luterbacher (1985) for Paleocene and Eocene, and Bolli and Saunders (1985) for Oligocene to Holocene. During the four decades following the publication of these magnificent taxonomic monographs, the planktic foraminiferal systematics has been revised and updated, at least at genus and species levels. Among the most relevant, we could highlight the following: Banner and Desai (1988), Nederbragt (1991), Berggren and Norris (1997), BouDagher-Fadel et al. (1997), Olsson et al. (1999), Moullade et al. (2002), Korchagin (2003), Pearson et al. (2006, with 16 chapters), Huber and Leckie (2011), Arenillas and Arz (2017) and Wade et al. (2018, with 20 chapters), as well as the numerous works led by M. D. Georgescu (see citations throughout the text).

The most active planktic foraminiferal taxonomists are currently BouDagher-Fadel $(2012,2015)$ and authors of pforams@mikrotax website (Young et al., 2017). They have reported the most recent compilations of described planktic foraminiferal species. The spiral planktic foraminiferal systematic of BouDagher-Fadel $(2012,2015)$ is based mainly on previous phylogenetic proposals by Banner and Blow (1965), Blow (1979), Banner (1982), Banner and Desai (1988) and BouDagher-Fadel et al. (1997), which are updated in 
light of more recent studies. The planktic foraminiferal systematics of the pforams@mikrotax website (Young et al., 2017) is based on the work and publications of various planktic foraminiferal taxonomic working groups (e.g., Kennet \& Srinivasan, 1983; Olsson et al., 1999; Pearson et al., 2006; Georgescu \& Huber, 2009; Huber \& Leckie, 2011; Aze et al., 2011; Wade et al., 2018).

The planktic foraminiferal phylogeny (Figs. 1-3) and classification postulated here is based mainly on those of BouDagher-Fadel (2012, 2015) and pforams@ mikrotax website (Young et al., 2017), with the incorporation of the new suprageneric taxa defined here and some old and recent taxa and phylogenetic proposals from other authors (Blow, 1979; Kennett \& Srinivasan, 1983; Loeblich \& Tappan, 1987; Nederbragt, 1991; Korchagin, 2003; Georgescu, 2009a, 2013a, 2013b, 2013c, 2015; Georgescu \& Huber, 2009; Huber \& Leckie, 2011; Georgescu et al., 2011; Georgescu \& Henderson, 2014). As the objective of this paper is not an exhaustive taxonomic study at the genus level, we have preserved a large part of the genera considered by all these taxonomists.

Some phylogenetic and taxonomic proposals illustrated in the Figures 1-3 are controversial. A summary of the main controversies is provided in the supplementary information. Among the globotruncanids, there are controversies regarding to the identification of the first appearance of truly planktic foraminifera, and to the number of genera and lineages of hedbergellids, rugoglobigerinids, globotruncanids, rotaliporids, globigerinelloids and planomalinoids (see supplementary text S2). Among the heterohelicids, controversies about the origin and evolution of the multiserial heterohelicids, spiroplectids and other heterohelicid lineages stand out (see supplementary text S3). Among the guembilitriids, the taxonomic positions of genera Cassigerinella Pokorný, 1955, and Jenkinsina Haynes, 1981, are the most problematic (see supplementary text S4). Taxonomic and phylogenetic controversies between globigerinids are more numerous (see supplementary text S5), highlighting the type of wall surface/texture of parvularuglobigerinoids, the validity of the families Globigerapsidae Blow, 1979, and Planorotalitidae BouDagher-Fadel, 2012, the taxonomic position of globanomalinoids, and the number of genera and lineages between globorotaloids and globigerinoids.

An example of controversy is the numerous evolutionary lineages of heterohelicids suggested by Georgescu (2013a, 2013b), Georgescu et al. (2013) and Georgescu and Henderson (2014), who have conducted the most extensive review of heterohelicids carried out to date. Some of these heterohelicid lineages contradict the traditional phylogenetic proposals of Nederbragt (1991). Nevertheless, their phylogenetic analyses demonstrate that the evolution of planktic foraminifera is much more complex than previously thought, with many examples of convergent, parallel and iterative evolution that cannot be unravelled without highresolution stratophenetic studies.

\section{POLYPHYLETIC ORIGIN OF THE PLANKTIC FORAMINIFERA}

\section{Evidence of a benthic origin for globotruncanids}

The first benthic-planktic transition in the evolutionary history of foraminifera remains controversial. Many Triassic and Early Jurassic taxa have been suggested as planktic (Fuchs, 1967, 1973, 1975; see supplementary text S2), but later had to be reinterpreted as benthic (BouDagher-Fadel, 2012, 2015). According to most specialists (e.g., Tappan \& Loeblich, 1988; Wernli, 1988, 1995; Hart et al., 2002, 2003; Wernli \& Görög, 2007), the first planktic foraminiferal genus was Conoglobigerina Morozova, 1961, in Morozova and Moskalenko (1961), or alternatively Globuligerina Bignot \& Guyader, 1971. The Conoglobigerina-Globuligerina group seems to have derived in the Middle Jurassic from the family Oberhauserellidae Fuchs, 1970 (Fig. 1), which includes benthic foraminifera with aragonitic tests (order Robertinida Mikhalevich, 1980). Gorbachik and Kuznetsova (1986) and BouDagher-Fadel et al. (1997) found evidence that the globuligerinids, as the oberhauserellids, have aragonitic tests. Furthermore, they suggested that, although most likely calcitic, the tests of conoglobigerinids could also be aragonitic, because the secondary nature of the calcite of their tests cannot be ruled out. The oberhauserellid genera Praegubkinella Fuchs, 1967, which is a descendent of Oberhauserella Fuchs, 1967, have been proposed as the direct ancestor of Conoglobigerina (Fuchs, 1975; Wernli, 1988, 1995; BouDagher-Fadel et al., 1997). Nevertheless, von Hillebrandt (2012) and Clemence and von Hillebrandt (2013) have questioned the agaragonitic nature of Conoglobigerina and Globuligerina, so doubts persist as to which was the true benthic ancestor of the first planktic foraminifera.

\section{Evidence of a benthic origin for heterohelicids}

The phylogenetic origin of heterohelicids has traditionally been sought among conoglobigerinids. Fuchs (1975) proposed to the conoglobigerinid Eoheterohelix Fuchs, 1973, as their most direct ancestor, which descended from Conoglobigerina through Woletzina Fuchs, 1973. However, Loeblich and Tappan (1987) and BouDagherFadel $(2012,2015)$ warned that the Fuchs's material consists mainly of poorly preserved specimens, and probably belonged to recrystallized benthic specimens of the family Oberhauserellidae. On the other hand, Georgescu (2009a) ruled out the other two possible alternatives for a planktic origin of the heterohelicids: 1) heterohelicids come from a contemporary (Albian) genus, either trochospiral (e.g., Hedbergella Brönnimann \& Brown, 1958, or Ticinella Reichel, 1950) or planispiral (e.g., Globigerinelloides Cushman 


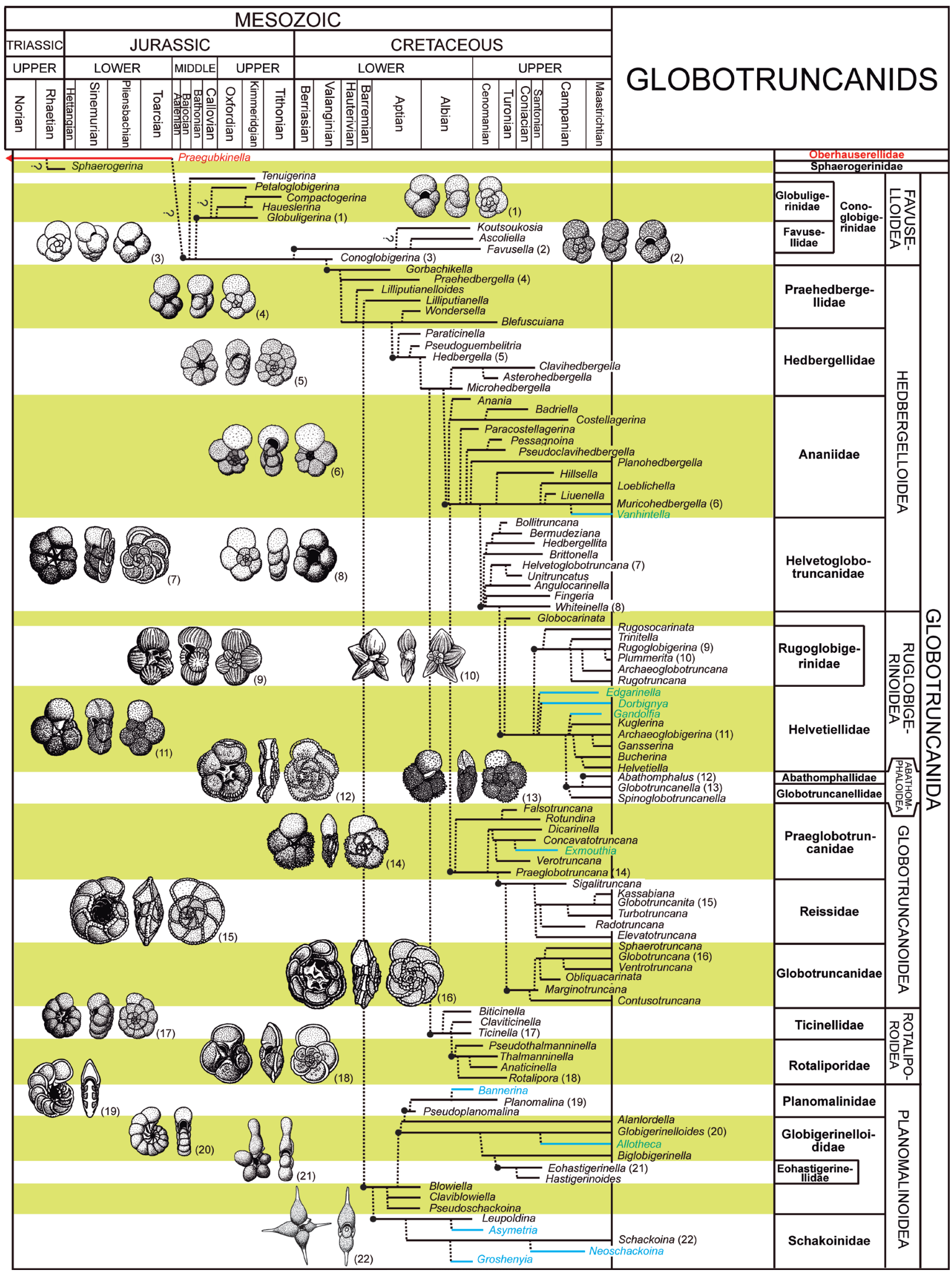

Figure 1. Benthic origin and evolutionary tree at the genus level of the order Globotruncanida $n$. ord. The phylogenetic relationships are based mainly on Caron (1985), Korchagin (2003), Huber and Leckie (2011), and BouDagher-Fadel (2012, 2015). In red, bio-chronostratigraphic ranges of benthic foraminiferal taxa. In blue, bio-chronostratigraphic ranges of evolutionary lineages proposed by Georgescu (see citations throughout the text, and supplementary text S2). Genus drawings are modified from or inspired by those of Banner (1982). Each node (black circle) represents the last common ancestor of each suggested phylogenetic group or suprageneric taxa. 
\& ten Dam, 1948); and 2) heterohelicids come from a species of Archaeoguembelitria Georgescu, 2009a. The first hypothesis was rejected because the earliest heterohelicids lack an early trochospiral or planispiral stage. The second hypothesis was disproved due to the relatively narrow variability of the Archaeoguembelitria species, which presents only triserial tests without any trend to develop biserial chamber arrangement. Consequently, Georgescu (2009a) concluded that the most likely alternative is a benthic origin.

The earliest heterohelicid, Protoheterohelix Georgescu \& Huber, 2009, may have derived from the benthic genus Praeplanctonia Georgescu, 2009a, a direct descendent of the buliminid genus Pleurostomella Reuss, 1860 (Fig. 2). According to Georgescu (2009a) and Georgescu and Huber (2009), the microperforate smooth wall, the asymmetry of its test and the periapertural structures of Protoheterohelix are a vestige of its benthic ancestor, i.e., Praeplanctonia. Protoheterohelix gave rise to several lineages and, later, these to the rest of heterohelicid members. BouDagher-Fadel $(2012,2015)$ instead suggested the buliminid genus Brizalina Costa, 1856, as ancestor of heterohelicids, adducing that it evolved in the late Albian changing their mode of life from being infaunal benthic dwellers of continental shelves to being planktic inhabitants of the surface waters of the open ocean.

\section{Evidence of a benthic origin for guembelitriids}

It is well known that Guembelitria Cushman, 1933, was probably the sole survivor of the CretaceousPaleogene boundary (KPB) mass extinction (Smit, 1982; Arenillas \& Arz, 2017), but its origin is uncertain. Fuchs (1975) proposed Conoglobigerina as the ancestor of guembelitriids. However, since Guembelitria did not appear until the Santonian (or until Cenomanian in the case that the species of Archaeoguembelitria were considered guembelitriids), this group of triserial planktic foraminifera cannot belong to the same phylogenetic group as Conoglobigerina, which became extinct at the Valanginian (Figs. 1-2). Again, the most plausible alternative is a benthic origin. Georgescu (2009a), Georgescu et al. (2011) and BouDagher-Fadel (2012, 2015) suggested Praebulimina Hofker, 1953, Pyramidina Brotzen, 1948, or most likely Neobulimina Cushman \& Wickenden, 1928, which belong to the family Turrilinidae Cushman, 1927, as possible benthic ancestors of the guembelitriids (Fig. 2).

There is stronger evidence that the guembelitriids are the ancestor of two incoming Danian lineages (Olsson et al., 1999; BouDagher-Fadel, 2012, 2015): the biserial chiloguembelinids, whose main member is Chiloguembelina Loeblich \& Tappan, 1956, and trochospiral globoconusids, whose main member is Globoconusa Khalilov, 1956 (Figs. 2-4). The early Danian genus Chiloguembelitria Hofker, 1978, played an important evolutionary role because it is the common ancestor of chiloguembelinids and globoconusids
(Arenillas et al., 2017). The first representative of the chiloguembelinids was the genus Woodringina Loeblich \& Tappan, 1957, which exhibits a mixed triserial-biserial test, and that of the globoconusids was the genus Trochoguembelitria Arenillas, Arz \& Náñez, 2012, which exhibits a mixed triserial-trochospiral test, at least in its early forms (see Arenillas et al., 2012, 2016, 2017). We should note that the Trochoguembelitria species were attributed to Parvularugoglobigerina Hofker, 1978, by Olsson et al. (1999; see discussion above), or to Postrugoglobigerina Salaj, 1986, by Loeblich and Tappan (1987) and BouDagher-Fadel (2012, 2015; see supplementary text S5).

\section{Evidence of a benthic origin for globigerinids}

The evolutionary origin of cenozoic globigerinids is controversial because both benthic and planktic ancestors have been proposed (see discussion in Arenillas \& Arz, 2017). Most experts take for granted that they descended from muricate hedbergellids (Muricohedbergella Huber \& Leckie, 2011), which includes generalist species that, according to them, survived the KPB catastrophic mass extinction event. Both BouDagher-Fadel $(2012,2015)$ and authors of pforams@mikrotax website (Young et al., 2017), the latter based on phylogenies of Olsson et al. (1999) and Aze et al. (2011), take for granted that the globigerinids evolved from muricate hedbergellids, and therefore keep the globotruncanids within the order Globigerinida. By contrast, Brinkhuis and Zachariasse (1988) and Arenillas and Arz (2017) postulated that the first cenozoic globigerinids evolved in the earliest Danian from the buliminid genus Caucasina Khalilov, 1951 (Figs. 3-4). They noted that muricate hedbergellids remained morphologically and texturally well separated from the earliest Cenozoic species. The latter were tiny globigeriniform species of microperforate, smooth wall (later called parvularugoglobigerinids), which rapidly evolved after the KPB extinction (Luterbacher \& Premoli-Silva, 1964; Smit, 1982; Brinkhuis \& Zachariasse, 1988; Arenillas \& Arz, 2000). The first member of the parvularugoglobigerinids was Pseudocaucasina Arenillas \& Arz, 2016 in Arenillas and Arz (2017), which is morphologically very similar to some Jurassic species of Conoglobigerina.

Muricohedbergella is commonly considered the ancestor of two lineages that appeared in the early Danian: globanomalinids and eoglobigerinids (e.g., Berggren, 1962; Bandy, 1967; Olsson, 1970; Fordham, 1986; Olsson et al., 1992, 1999; Liu \& Olsson, 1994; Berggren \& Norris, 1997; Apellániz et al., 2002; Aze et al., 2011; BouDagher-Fadel, 2012, 2015; Koutsoukos, 2014). However, after ascertaining that their stratigraphic ranges do not overlap in the lower Danian, Arenillas and Arz (2000) disproved Muricohedbergella as the ancestor of both lineages. In addition, Arenillas et al. (2018) raised doubts that Muricohedbergella was a real survivor of the KPB extinction event. According 


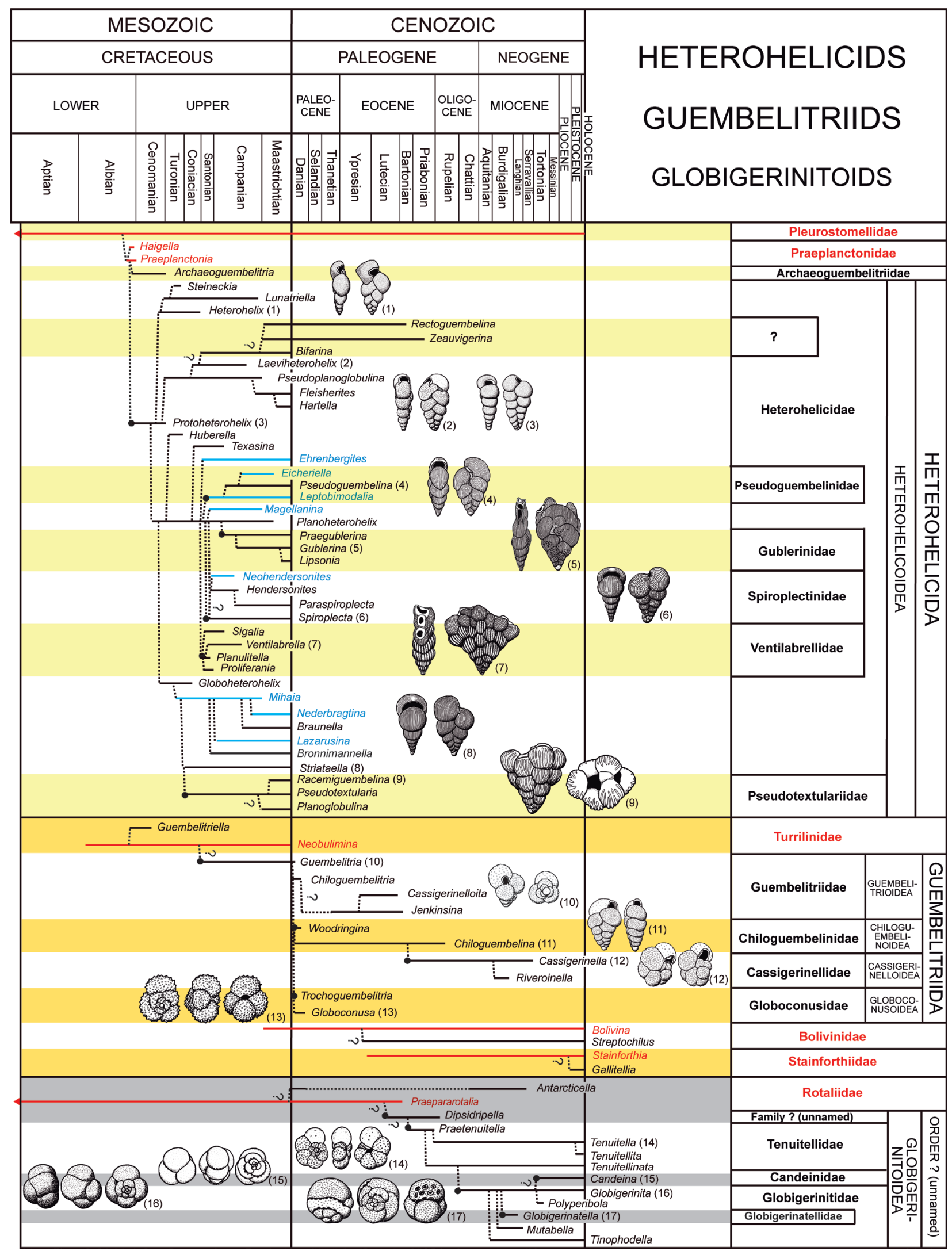

Figure 2. Benthic origin and evolutionary tree at the genus level of the orders Heterohelicida and Guembelitriida $\mathrm{n}$. ord. The phylogenetic relationships are based mainly on Nederbragt (1991), Georgescu and Huber (2009), Georgescu et al. (2011), BouDagher-Fadel (2012, 2015), Georgescu (2013a, 2013b), and Arenillas et al. (2012, 2016, 2018). In red, bio-chronostratigraphic ranges of benthic foraminiferal taxa. In blue, bio-chronostratigraphic ranges of evolutionary lineages proposed by Georgescu (see citations throughout the text, and supplementary text S3). Genus drawings are inspired by those of Banner (1982). Each node (black circle) represents the last common ancestor of each suggested phylogenetic group or suprageneric taxa. 
to Arenillas et al. (2018), the most plausible alternative is a benthic origin for the parvularugoglobigerinids, which would be more consistent with the molecular phylogenetic studies suggesting the order Globigerinida could have originated after the KPB (e.g., Aurahs et al., 2009).

Huber et al. (2020) have recently rejected this hypothesis, under the assumption that, unlike Caucasina, Parvularugoglobigerina exhibits poremounded wall (see supplementary text S5), as claimed by Liu and Olsson (1992) and Olsson et al. (1992, 1999). However, Arenillas and Arz (2000) could not confirm this surmise after reviewing the holotypes of the main parvularugoglobigerinid species defined by Luterbacher and Premoli-Silva (1964) at Gubbio (Italy), as well as the type sample of the Parvularugoglobigerina eugubina Zone at Ceselli (Italy), which is characterized by this assemblage of tiny globigerinids. Conversely, several high-resolution stratophenetic studies verify that parvularugoglobigirenids exhibits smooth wall texture in well-preserved specimens (Fig. 4) from the most complete and continuous lower Danian sections worldwide (e.g., Smit, 1982; Brinkhuis \& Zachariasse, 1988; Li \& Radford, 1991; Li et al., 1995; Arenillas \& Arz, 2000, 2017). The assumption of Huber et al. (2020) lies probably in attributing to Parvularugoglobigerina the diagnostic characters of the more modern and larger globoconusid genus Trochoguembelitria, whose first appearance occurred almost at the same time as eoglobigerinids and globanomalinids (Fig. 4), acquiring gross morphologies very similar to real parvularugoglobigerinids (Arenillas et al., 2016).

\section{The enigmatic origin of the globigerinitoids}

Candeinids, globigerinitids, globigerinatellids and tenuitellids appear to form a phylogenetic unit of enigmatic origin, which have been grouped in the superfamily Globigerinitoidea BouDagher-Fadel, 2012. The phylogenetic relationships between them still remain ambiguous. There is both stratophenetic and molecular evidence (Blow, 1979; Ujiié \& Lipps, 2009) of a close relationship between Candeina d'Orbigny, 1839, and Globigerinita Brönnimann, 1951. The tenuitellids also appear to be closely related to globigerinitids, but there is no genetic evidence yet. Blow (1979), Kennett and Srinivasan (1983) and Li (1986), among others, suggested that the extinct genus Globigerinatella Cushman \& Stainforth, 1945, and consequently the globigerinatellids, are also closely related to globigerinitids and candeinids. All of them may belong to the same phylogenetic group originated from the benthic ancestor conjectured by Ujiié et al. (2008) for the candeinids (see discussion below).

Pearson et al. (2018) have recently suggested that the microperforate, trochospiral genus Dipsidripella Brotea, 1995 (see supplementary text S6), was the first globigerinitoid to evolve (in the middle Eocene), giving rise to tenuitellids and, later, the latter to the rest of globigerinitoid members. Although initially considered uncertain (Huber et al., 2006), the evolutionary origin of Dipsidripella may be related to the rotaliid genus Praepararotalia Liu, Olsson \& Huber, 1998. Since a benthic ancestor has been proposed as the origin of this group (de Vargas et al., 1997; Ujiié et al., 2008; Ujiié \& Lipps, 2009; Pearson et al., 2018), and thus disconnecting them from the other planktic foraminiferal lineages, a new order should be erected to separate them from the order Globigerinida (Fig. 2). However, until their phylogenetic relationships are clarified, it is advisable for now not to define it. If it is confirmed that they form an independent phylogenetic group of planktic foraminifera, the simplest solution would be to elevate the superfamily Globigerinitoidea to order Globigerinitida.

\section{Do candeinids and globorotaloids have independent benthic origins?}

Testing different hypotheses on the phylogenetic relationships between and within the major groups of current planktic foraminifera using SSU-rDNA sequences, de Vargas et al. (1997) concluded that there have been at least three independent events of benthic-planktic transition in the history of modern planktic foraminiferal families: Globigerinidae (and Hastigerinidae Bolli, Loeblich \& Tappan, 1957), Globorotaliidae Cushman, 1927, and Candeinidae Cushman, 1927. After new SSU-rDNA molecular studies, Aurahs et al. (2009) reached very similar conclusions, evidencing the phylogenetic relationships of the cenozoic planktic foraminifera remained ambiguous. Morphologically, these families are differentiated by the wall structure and surface (Saito et al., 1981; Kennett \& Srinivasan, 1983; Hemleben et al., 1989). The genera of the first two families are usually characterized by having more globular tests and a spinose wall, either cancellate (Globigerinidae) or pitted (Hastigerinidae). The Globorotaliidae genera are usually characterized by having more flattened tests and a nonspinose, pitted to smooth wall. Finally, the Candeinidae genera exhibit tiny tests and microperforate, smooth wall. According to de Vargas et al. (1997) and Aurahs et al. (2009), Globigerinidae could originate after the KPB mass extinction, and the other two after the minor extinction event of the Eocene-Oligocene transition (EOT).

De Vargas et al. (1997) indicated that the assumption of the divergence of globorotaliids and candeinids in the Neogene from globigerinoid ancestors was not supported by molecular phylogeny. They suggested that the candeinids, which appeared in the fossil record during the EOT crisis, exhibit closer molecular relationships with benthic rotaliids and/or textulariids than with globigerinids. The relationships between globorotaliids and rotaliids-textulariids also are strongly suggested by ribosomal DNA sequence similarities. In 


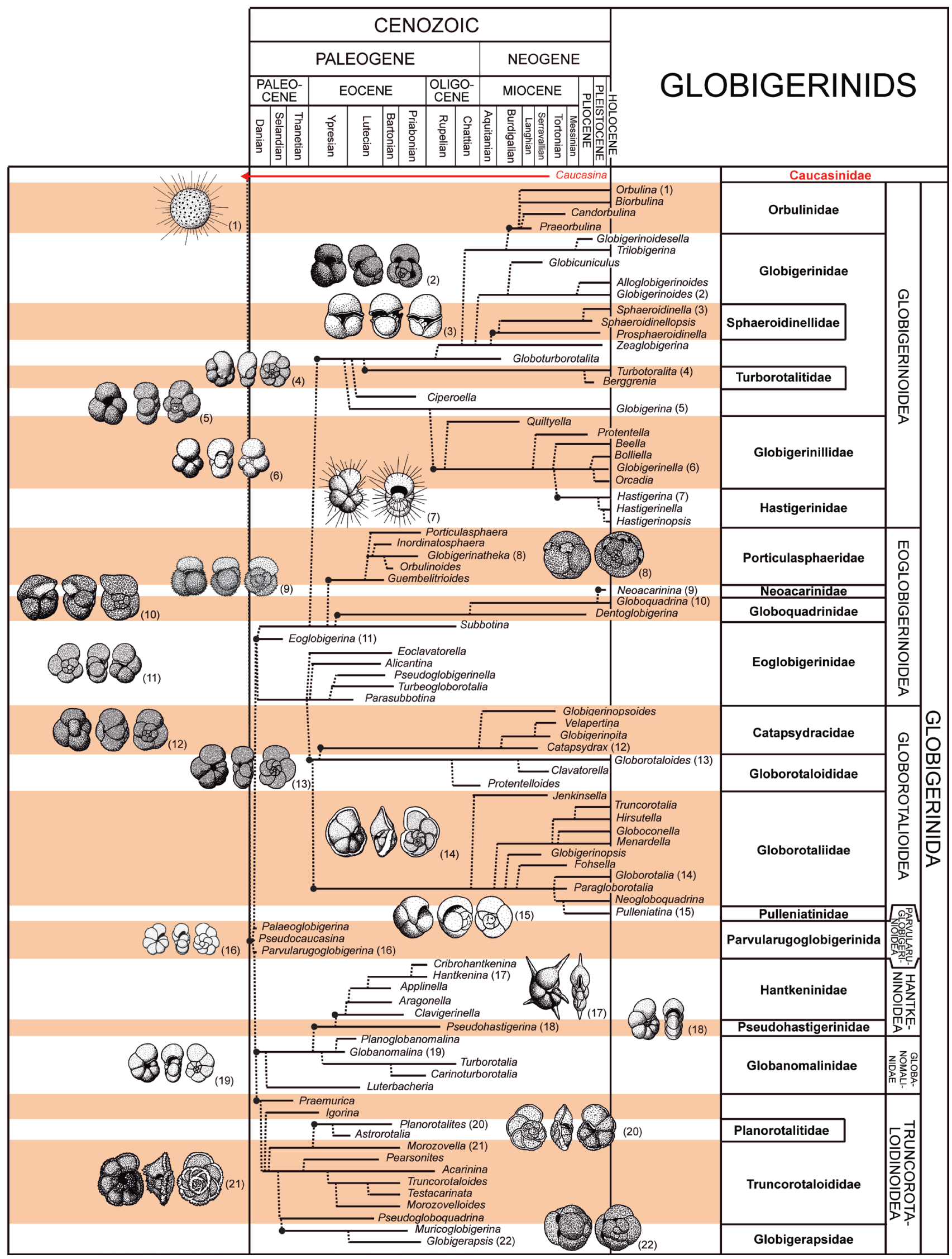

Figure 3. Benthic origin and evolutionary tree at the genus level of the order Globigerinida. The phylogenetic relationships are based mainly on Olsson et al. (1999), Pearson et al. (2006), Aze et al. (2011), BouDagher-Fadel (2012, 2015), Arenillas and Arz (2017), Wade et al. (2018) and Arenillas et al. (2018). In red, bio-chronostratigraphic ranges of benthic foraminiferal taxa. Genus drawings are modified from or inspired by those of Banner (1982). Each node (black circle) represents the last common ancestor of each suggested phylogenetic group or suprageneric taxa. 
addition, it has even been observed that globorotaliids show benthic behaviour in culture (Hemleben et al., 1989).

There is evidence that Candeinidae, as belonging to globigerinitids (see discussion above, and Fig. 2), could evolved from a benthic taxon after the EOT crisis (Pearson et al., 2018). On the contrary, it seems to be well established by stratophenetic evidence that globorotaloids evolved from a planktic ancestor in lower Eocene, being its first members Globorotaloides Bolli, 1957, and Paragloborotalia Cifelli, 1982 (Olsson et al., 2006a, 2006b; Aze et al., 2011). If the stratophenetic data are correct (Aze et al., 2011), globigerinoids and globorotaloids evolved from eoglobigerinoids, the first from Subbotina Brotzen \& Pożaryska, 1961, and the second from Parasubbotina Olsson, Hemleben, Berggren \& Liu, 1992 (Fig. 3). The common ancestor of these two genera was Eoglobigerina Morozova, 1959, and their divergence occurred shortly after the KPB mass extinction event (Arenillas \& Arz, 2013a, 2013b). This account for the apparent phylogenetic disconnection between both groups (globigerinoids and globorotaloids) according to the SSU-rDNA molecular studies. In any case, if an independent benthic origin for globorotaloids is demonstrated, the superfamily Globorotalioidea Cushman, 1927, would have to be elevated to the order category.

\section{MORE EXAMPLES OF MULTIPLE INVASIONS OF BENTHIC FORAMINIFERA TO THE PELAGIC DOMAIN}

Leckie (2009) noted that the ancestry of a number of planktic foraminiferal lineages remains a mystery. The iterative origin of planktic taxa with a microperforate wall, either smooth, pore-mounded or finely pustulate (hispid), during the Mesozoic and Cenozoic is poorly known: Sphaerogerina Korchagin \& Kuznetsova, 2003, in the Rhaetian (Late Triassic), Conoglobigerina in the Bajocian (Middle Jurassic), Archaeoguembelitria and Protoheterohelix in latest Albian, Guembelitria and Bifarina Parker \& Jones, 1872, in the Santonian, Zeauvigerina Finlay, 1939, and Rectoguembelina Cushman, 1932, in the Maastrichtian, Pseudocaucasina in the earliest Danian, Cassigerinella in the Bartonian, Dipsidripella in the Lutecian, Tenuitella Fleisher, 1974, in the Rupelian, Antarcticella Loeblich \& Tappan, 1987, in the Chattian (or in the earliest Danian according to Liu et al., 1998), Candeina in the Tortonian, and Gallitellia Loeblich \& Tappan, 1986, in the Pleistocene. All may have had benthic ancestors and being the result of multiple invasions of benthic foraminifera to the pelagic domain.

\section{Benthic origins of other globotruncanid-type taxa}

Korchagin et al. (2003) described a globigeriniform planktic genus in the Triassic: Sphaerogerina, which first appeared in the Rhaetian, and did not survive the End-Triassic mass extinction event. They phylogenetically related Sphaerogerina to favuselloids, specifically to a Globuligerina species that according to them lived in the Rhaetian. However, BouDagher-Fadel $(2012,2015)$ warned that this species is probably an agglutinated benthic foraminifer. In addition, since Sphaerogerina went extinct at the end of the Triassic, they cannot belong to the same phylogenetic group as the true favuselloids, which did not appear until the Middle Jurassic. On phylogenetic grounds, BouDagherFadel (2012) placed Sphaerogerina in a new family: Sphaerogerinidae. BouDagher-Fadel (2012, 2015) suggested that, like Conoglobigerina, Sphaerogerina emerged from oberhauserellids in an independent benthic-planktic transition (Fig. 1).

\section{Benthic origins of other heterohelicid-type taxa}

Some cretaceous heterohelicid-type genera are also considered descendants of benthic ancestors. The most notable are the biserial genera, with a tendency to become uniserial, such as Bifarina, Zeauvigerina, and Rectoguembelina. They have been related to heterohelicids (Fig. 2), as descendants of Heterohelix Ehrenberg, 1843, or more likely of Laeviheterohelix Nederbragt, 1991 (see, for example, Huber \& Boersma, 1994; Olsson et al., 1999; Huber et al., 2006; BouDagher-Fadel, 2012, 2015). Stable isotopic evidence that some of their species are planktic have been reported by Huber and Boersma (1994) and D'Haenens et al. (2012). However, there are still doubts that all their species have a planktic mode of life. Loeblich and Tappan (1987) included Zeauvigerina in the buliminid family Loxostomatidae Loeblich \& Tappan, 1962. Olsson and Leckie (1994) considered Bifarina as a benthic foraminifer inhabiting of inner and middle sublittoral environments in epicontinental seas. Rectoguembelina, which was synonymized with Bifarina and Tubitextularia Šulc, 1929, by Loeblich and Tappan (1964, 1987), was originally considered benthic (see Stainforth et al., 1975). There is also the possibility that at any stage of their life and under stressful conditions they swapped their mode of life from benthic to planktic or vice versa (BouDagherFadel, 2012, 2015).

\section{Benthic origins of other guembelitriid-type taxa}

Examples of guembelitriid-type genera with an independent benthic origin are Archaeoguembelitria, Streptochilus Brönnimann \& Resig, 1971, and current Gallitellia (Fig. 2). Georgescu (2009a) erected the genus Archaeoguembelitria to include the latest Albianearliest Turonian triserial planktic foraminifera, regarded as phylogenetically unrelated to the Late Cretaceous genus Guembelitria. Archaeoguembelitria included both benthic and planktic species, and may have derived from another, different ancestral benthic lineage (Georgescu, 2009a): the buliminid Praeplanctonia, 


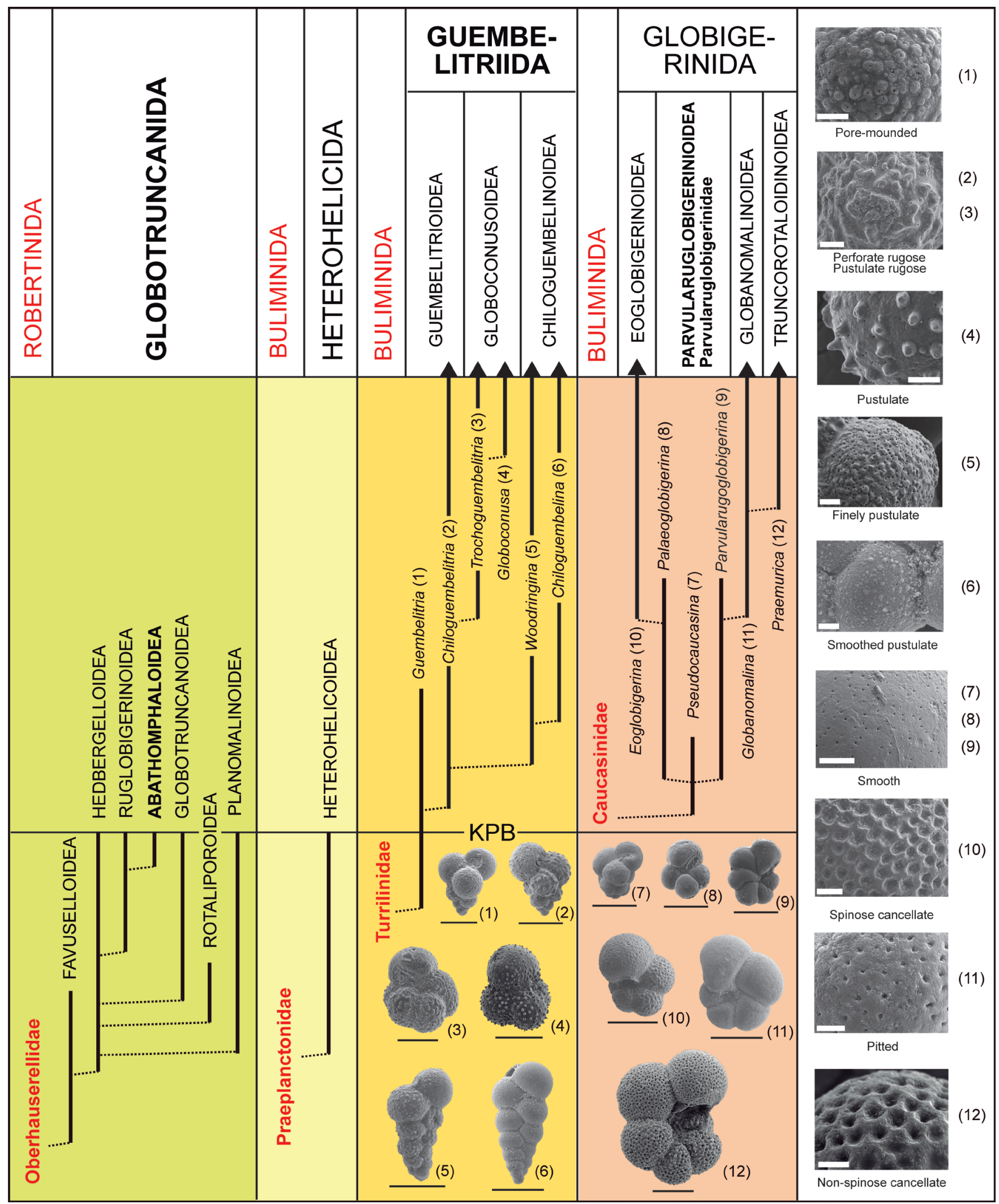

Figure 4. Benthic origins and evolutionary trees of the orders Globotruncanida, Heterohelicida, Guembelitriida and Globigerinida, based on the most up-to-date phylogenetic proposals (see discussion in main text and supplementary information), the first two at the superfamily level, and the last two at the genus level and only for the early Danian. This figure includes wall textures/surfaces of early Danian genera of Guembelitriida and Globigerinida. Note that the wall surface of parvularuglobigerinids is smooth, and microperforate to finely perforate. Note also that the wall surface of Trochoguembelitria is microperforate, pore-mounded to rugose (see discussion in main text and supplementary information). Defined taxa are in bold font; scale bar $=100 \mu \mathrm{m}$; scale bar of wall details $=5 \mu \mathrm{m}$. 
which is also the ancestor suggested for the first heterohelicid genus (Protoheterohelix). The typical pore-mounded wall of triserial planktic foraminifera, such as Guembelitria and Archaeoguembelitria, could be an adaptation that improved the ability to float (Dubicka \& Wierzbowski, 2019).

The biserial genus Streptochilus was originally considered a descendant of Chiloguembelina (see, for example, Stainforth et al., 1975; Kennett \& Srinivasan, 1983; Huber et al., 2006). However, Darling et al. (2009) demonstrated that the extant planktic Streptochilus globigerus (Schwager, 1866) and the benthic Bolivina variabilis (Williamson, 1858) are the same biological species. Therefore, Streptochilus seems to include ecologically flexible species actively grow within the open-ocean waters, occupying both pelagic and benthic domains (Smart \& Thomas, 2018). When they are planktic, they inhabit surface and thermocline of the open ocean and, when they are benthic, they live as shallow to intermediate infaunal dwellers. Smart and Thomas (2007) even suggested that the Streptochilus species may have evolved polyphyletically.

Based on molecular evidence, Ujiié et al. (2008) indicated that the modern triserial genus Gallitellia, of microperforate, smooth wall, may have evolved in the Miocene from the buliminid genera Stainforthia Hofker, 1956, or alternatively Virgulinella Cushman, 1932. They also noted that the sporadic occurrence of triserial planktic foraminifera in the fossil record may reflect multiple transitions from a benthic to a planktic mode of life.

\section{Benthic origins of other globigerinid-type taxa}

A globigerinid-type taxon of uncertain origin is Antarcticella, which was endemic to high southern latitudes (Loeblich \& Tappan, 1987; BouDagherFadel, 2012, 2015). This genus inhabited shallower environments of marginal basins, and probably includes both benthic and planktic species (Liu et al., 1998; Malumián \& Náñez, 2011; Huber et al., 2020). It was initially considered late Oligocene-middle Miocene in age and included among the globigerinitids (Loeblich \& Tappan, 1987). However, Liu et al. (1998) claimed that Antarcticella originated immediately after the KPB mass extinction event, evolving from the rotaliid Praepararotalia (Fig. 2). As previously suggested by Leckie and Webb (1985), Liu et al. (1998) surmised that Antarcticella was the direct ancestor of Candeina. However, the hypothesis that suggests Dipsidripella as the ancestor of the globigerinitoids, to which the candeinids belongs, is gaining more acceptance among taxonomists (Pearson et al., 2018). Therefore, Antarcticella seems to belong to another different lineage descended from benthic foraminifera.
UNDERLYING CAUSES OF THE JUMP FROM BENTHOSTOPLANKTONIN FORAMINIFERA

Taxonomists have postulated benthic ancestry hypotheses for all planktic foraminiferal taxa and lineages described above, but the causes that have induced the jump from benthic to planktic mode of life are still unclear. A first clue can be found in the habitat and ecological niche that they or their benthic ancestors occupied, including their depth habitat, ecological strategy (specialists, generalists, opportunists), and mode of life (holobenthic, meroplanktic, tychoplanktic or holoplanktic). Other clues may emerge after checking whether or not their first appearances coincide with environmental crises or ecological stress events. Additionally, identifying the taxonomic group to which their benthic ancestor belongs can also help to understand why the jump from benthos to plankton occurred.

\section{Dwellers of near-surface ocean waters}

Many of the taxa more closely related to their benthic ancestors inhabited exclusively neritic environments of epicontinental seas. Others became also successful in the oceanic realm, mainly in continental margins. The neritic environment, probably close to continental margins, was the preferred habitat for the first Jurassic favuselloids, i.e., Conoglobigerina and Globuligerina (Gordon, 1970; Hart et al., 2002, 2003; Hudson et al., 2009; Gradstein et al., 2017; Kendall et al., 2020; Gajewska et al., 2021). Protoheterohelix and its closest descendants (e.g., Planoheterohelix Georgescu \& Huber, 2009) were inferred to be upper mixed layer dwellers (Nederbragt, 1991; Nederbragt et al., 1998). Guembelitria lived mainly on shelf areas (Smith \& Pessagno, 1973; Leckie, 1987) but they were also abundant in paleo-upwelling areas of the continental margins (Kroon \& Nederbragt, 1990). Biogeographic and oxygen isotopic data suggest that Guembelitria inhabited a near-surface planktic niche (Boersma et al., 1979; Boersma, 1984; D'Hondt \& Zachos, 1993; Olsson et al., 1999). Similar niche and habitat are occupied by the current Gallitellia, which lives mainly over shelf areas, in semi-enclosed basins, and in upwelling areas, being rare in the open ocean (Kroon \& Nederbragt, 1990). Regarding Pseudocaucasina and the rest of the smooth-walled parvularugoglobigerinids, there are no stable isotope evidence available on their habitat. Nevertheless, paleobiogeographic data indicate that they inhabited in the open ocean, occupying the surface waters of external neritic and oceanic environments (Arenillas \& Arz, 2017).

Other examples include Antarcticella, which inhabited shallow environments of marginal basins (Liu et al., 1998; Malumián \& Náñez, 2011; Huber et al., 
2020), Bifarina and Zeauvigerina, which preferably inhabited inner and middle neritic environments with a restricted geographic distribution (Leckie, 2009), and Rectoguembelina, which seems to have also inhabited upper surface waters in open sea (Huber \& Boersma, 1994). Doubts persist as to whether all species of Bifarina and Zeauvigerina are planktic (see Huber et al., 2006). For example, Bifarina has been reported occurring in nearshore sediments (Olsson \& Leckie, 1994). Something similar happens with Dipsidripella because there are doubts as to whether it was benthic for part of its life cycle or it was planktic occupying a much deeper habitat than co-occurring planktic foraminifera (Huber et al., 2006). Current Streptochilus and Tenuitella are, on the contrary, from deeper habitat, the former inhabiting the thermocline (Resig \& Kroopnick, 1983), and the latter preferably living within the oxygen minimum zone (Huber et al., 2006; Pearson et al., 2018).

\section{Opportunists in episodes of global environmental stress}

Several of the evolutionarily basal genera mentioned above have been described as opportunistic forms, which allowed them to acquire ecological advantage in times of environmental stress for the microplankton communities. For example, some environmental crisis could favour the evolution of the conoglobigerinids from the oberhauserellids in the Middle Jurassic. Fuchs (1975) suggested that the change in the test mineralogy from aragonite to calcite in the conoglobigerinids was likely due to the climate cooling that occurred in the Early Jurassic, as well as the reduction in the magnesium content in the oceans. However, Hart et al. $(2002,2003)$ suggested that the origin of conoglobigerinids was one of the probable results of the early Toarcian oceanic anoxic event. An alternative explanation was provided by BouDagherFadel $(2012,2015)$, who suggested that the sudden appearance of many of the Conoglobigerina species could be related to the rise in sea level of the Bajocian, which could open up new niches. According to Leckie (2009), fluctuating sea level and changing conditions of the oxygen minimum zone and the phytoplankton community structure were three of many factors that may have provided opportunities for benthic foraminifers to make the leap into the pelagic environment.

Among the opportunistic planktic foraminifera, Guembelitria is a paradigmatic example, since it has been described as small-sized disaster triserials, common to abundant in less stable palaeoenvironments, and tolerant to disturbed environments and under eutrophic conditions (Nederbragt, 1989; Kroon \& Nederbragt, 1990; Keller \& Pardo, 2004; Abramovich et al., 2010). Triserial guembelitriids have the potential to persist during times of drastically changing marine conditions, as recorded just after the KPB, when other species became extinct (Kroon \& Nederbragt, 1990). Other guembelitriid-type taxa, as Archaeoguembelitria (Eicher \& Worstell, 1970b, referred to as Guembelitria) and Gallitellia (Kroon \& Nederbragt, 1990), are also opportunists, being relatively abundant where environmental conditions are adverse for other species. Between the heterohelicids, Protoheterohelix, Planoheterohelix and Zeauvigerina are also considered opportunistic taxa (Nederbragt, 1991; Nederbragt et al., 1998; D'Haenens et al., 2012).

On the other hand, the immediate benthic ancestor of globigerinid Pseudocaucasina, i.e., Caucasina, has also been considered an opportunist, specifically a phytodetritivore tolerant to eutrophic, dysoxic environments (Poag, 1989, 2012; Koutsoukos \& Hart, 1990). The pelagic niches emptied after the KPB mass extinction event may have favoured Caucasina to invade the pelagic environment, giving rise to the parvularugoglobigerinids only a few thousand years later (Arenillas \& Arz, 2017). Something similar could have happened during the EOT crisis, as de Vargas et al. (1997) proposed. The climate cooling across the EOT (Priabonian and Rupelian) wiped out lineages that had dominated during the Paleogene (truncorotaloids, hantkeninoids, globanomalinoids, porticulasphaerids), allowing the evolutionary radiation of globigerinoids and globorotaloids, and the appearance of globigerinitoids (Dipsidripella-Tenuitella) from their benthic ancestor (Pearson et al., 2018). In summary, mass extinctions events may strongly have favoured repopulation from benthic ancestors.

\section{Meroplanktic and tychoplanktic modes of life}

It has been suggested that conoglobigerinids were meroplanktic taxa, i.e., planktic for only a part of their life cycle (Banner et al., 1985; BouDagher-Fadel et al., 1997; BouDagher-Fadel, 2012, 2015). The earliest known favuselloids (Conoglobigerina) have a discorbid-like early growth habit (Banner, 1982). They all have at least five to six chambers in the early whorls, while the last whorl has only four chambers. This discorbid-like morphology may indicate that they were benthic in the juvenile stage. However, the last whorls exhibit globular chambers, suggesting that they were planktic in the adult stage. The meroplanktic mode of life seems to have been associated with dimorphism by alternation of generations (i.e., dimorphic life cycle with microspheric and megalospheric forms), a character unknown in any holoplanktic foraminifera (BouDagher-Fadel, 2012, 2015). Consequently, the evolution of conoglobigerinids could occur initially by adopting a meroplanktic mode of life.

Such transitions from the benthic to the planktic mode of life are well documented in many modern rotaliids inhabiting of shelf environments (Banner et al., 1985; BouDagher-Fadel et al., 1997), as for example among 
discorboids (e.g., tretomphaloid-type rosalinids) and planorbulinoids (e.g., cymbaloporids). Hart et al. (2003) suggested that the perturbation created by the early Toarcian gas hydrate surge, and the ensuing oceanic anoxic event, could be the cause of the transition to a meroplanktic mode of life. The holoplanktic mode of life did not emerge until the appearance of Globuligerina in the Bathonian.

A similar case may be that of early parvularugoglobigerinids (Pseudocaucasina), which exhibit a juvenile stage with fourth to five chambers and an adult stage with three chambers (Arenillas \& Arz, 2017). Its benthic ancestor, Caucasina, which groups infaunal taxa that inhabit from inner sublittoral to bathyal (Poag, 1989, 2012; Koutsoukos \& Hart, 1990), display a similar morphology, with five to six chambers in the early whorls, and only two to three chambers in the last whorls (see Arenillas \& Arz, 2017). For comparison with conoglobigerinids, we can speculate that Caucasina and perhaps Pseudocaucasina were meroplanktic taxa.

Nonetheless, there is another possibility. Darling et al. (2009) claimed that the species surviving the KPB extinction, which have been described as inhabitants of shallow neritic environments (e.g., Guembelitria or Zeauvigerina), may very well have been tychoplanktic. Darling et al. (2009) suggested that radiation and repopulation of the empty niche in the plankton after the KPB extinction may at least in part have occurred from tychoplanktic benthic species rather than from neritic planktic ones. The tychoplanktics are species capable of living both in the benthic and in the pelagic domain, as demonstrated for current Bolivina variabilis/ Streptochilus globigerus. Such species are endowed with a great ecological advantage, enabling a rapid recolonization of the pelagic domain from the benthos (Leckie, 2009; Clemence \& von Hillebrandt, 2013). After mass extinctions in the plankton, as caused by bolide impacts, climate cooling or oceanic anoxic events, tychoplanktic species may well be capable of repopulating the pelagic realm and evolve into fully planktic forms (Darling et al., 2009).

Kucera et al. (2017) recently showed that the initial phase of the pelagic colonization by benthic taxa could even be achieved without external forcing, i.e., without environmental stress, through the evolution of a tychoplanktic mode of life, which may have evolved as a strategy for dispersal of benthic foraminifera. They speculated that the final step to switch from the tychoplanktic to holoplanktic mode of life could be the adoption of obligate sexual reproduction or suppression of the asexual phase of the life cycle. The existence of such meroplanktic or tychoplanktic modes of life in foraminifera provides a possible mechanism through which planktic lineages may have evolved multiple times from benthic ancestor since the Jurassic times (Darling et al., 2009; Clemence \& von Hillebrandt, 2013).
Relevance of buliminids as ancestors of planktic foraminifera

Most of the putative benthic ancestors of planktic foraminiferal groups are buliminids. This is the case of Praeplanctonia (ancestor of Protoheterohelix and Archaeoguembelitria), Neobulimina (ancestor of Guembelitria), Caucasina (ancestor of Pseudocaucasina), and Stainforthia (ancestor of Gallitellia). Streptochilus and Zeauvigerina may in fact be buliminids. Therefore, the buliminids seem to have played a relevant role as ancestors of various microperforate planktic foraminifera, with triserial or high trochospiral test and with pore-mounded or smooth wall. Buliminids are commonly infaunals that inhabited environments with a high nutrient supply and low levels of oxygen (Sen-Gupta \& Machain-Castillo, 1993; Bernhard et al., 1997).

Alve (1999) and Dubicka and Wierzbowski (2019) showed that some bi- and triserial benthic foraminiferal species of Cretaceous buliminid genera, such as Pseudouvigerina Cushman, 1927, Bolivinoides Cushman, 1927, Eouvigerina Cushman, 1926, and Loxostomum Ehrenberg, 1854, seem to have a propagule dispersal mechanism and the ability to occupy both pelagic and benthic domains (tychoplanktic mode of life). They exhibit microperforate wall with poremounded -and/or finely pustulate- surface, which is relatively rare in benthic foraminifera and more common in planktic foraminifera. It suggests that the poremounded wall stood for an exceptional morphological advantage, which iteratively evolved in buliminid foraminifera during the Mesozoic and Cenozoic, and could become a bridge between a benthic and planktic mode of life (Dubicka \& Wierzbowski, 2019).

The uvegirinid and bolivinid genera studied by Dubicka and Wierzbowski (2019) were grouped in the superfamily Serioidea by Holzmann and Pawlowski (2017) (see supplementary text S8). This superfamily also includes to the family Stainforthiidae Reiss 1963, which in turn probably comprises the current triserial planktic genus Gallitellia. The bimodal lifestyle, apparently linked to a pore-mounded wall, is likely characteristic of this superfamily, which can be interpreted as a link between benthic and planktic foraminifera, as already postulated by Georgescu et al. (2011).

The only exceptions may be Praegubkinella (ancestor of Conoglobigerina) and Praepararotalia (ancestor of Dipsidripella-Tenuitella and Antarcticella). As mentioned above, the former was a robertinid (oberhauserellid) and the latter a rotaliid. Praegubkinella, like Oberhauserella, was an opportunist tolerant to dysoxic conditions and stressed environments, and probably with a meroplanktic mode of life (BouDagher-Fadel, 2012, 2015; Clemence \& von Hillebrandt, 2013). Praepararotalia was an outer sublittoral dweller, that lived in relatively oxygen-depleted or food-enriched 
waters, and probably with a tychoplanktic mode of life (Liu et al., 1998; Huber et al., 2020). Consequently, both taxa have an ecological niche similar to many buliminids, and may have shared the same role as bridge between benthic and planktic modes of life.

\section{JUSTIFICATION FOR THE NEW DEFINED TAXA}

\section{New order Globotruncanida}

If the hypothesis that Cenozoic globigerinids evolved after the KPB extinction from the benthic genus Caucasina is verified, as proposed by Brinkhuis and Zachariasse (1988) and Arenillas and Arz (2017), then Mesozoic planktic foraminifera are phylogenetically disconnected from those of the Cenozoic. Even excluding heterohelicids as already postulated by Fursenko (1958) and BouDagher-Fadel (2012, 2015), the order Globigerinida becomes polyphyletic if the spiral Mesozoic taxa are included. It is therefore necessary to separate the latter in a new order, which we have called Globotruncanida, because the genus Globotruncana Cushman, 1927, and the family Globotruncanidae Brotzen, 1942, are the ones that best characterize it. Consequently, it is also necessary to emend the order Globigerinida.

This new order includes Conoglobigerina, the first planktic foraminifera to appear (if Sphaerogerina is excluded), as well as all its descendants (Fig. 1). Consequently, the order Globotruncanida appeared in the Bajocian (Middle Jurassic), and includes 7 superfamilies and 20 families. The globotruncanids reached at the Maastrichtian the largest test size of all planktic foraminifera, up to $1 \mathrm{~mm}$ in diameter as in the case of Contusotruncana Korchagin, 1982. For comparison, Cenozoic and current species do not exceed $600 \mu \mathrm{m}$ in diameter.

\section{New order Guembelitriida}

Fursenko (1958) joined all planktic foraminifera with biand triserial arrangement, at least in the early ontogenetic stage, in the order Heterohelicida, consequently clustering the families Heterohelicidae Cushman, 1927, Guembelitriidae Montanaro-Gallitelli, 1957, Chiloguembelinidae Loeblich \& Tappan, 1956, Globoconusidae BouDagher-Fadel, 2012, and Cassigerinellidae Bolli, Loeblich \& Tappan, 1957 (see BouDagher-Fadel, 2012, 2015). However, this order also becomes polyphyletic if the guembelitriids and their Cenozoic descendants (chiloguembelinids, globoconusids and cassigerinellids) are included. It is therefore necessary to separate these families in a new order, which we have called Guembelitriida, because the genus Guembelitria, and the family Guembelitriidae Montanaro-Gallitelli, 1957, are the ones that best characterize it. Consequently, it is also necessary to emend the order Heterohelicida. Guembelitriida $n$. ord. includes 4 families: Cassigerinellidae, Chi- loguembelinidae, Globoconusidae and Guembelitriidae (Fig. 2), which we have also elevated to the category of superfamily.

\section{New superfamily Abathomphaloidea}

The superfamily Abathomphaloidea has been defined to accommodate the families Globotruncanellidae Maslakova, 1964, and Abathomphalidae Pessagno, 1967, that form a phylogenetic group already recognized by Robaszynski et al. (1984). Abathomphalidae and Globotruncanellidae have traditionally been included in the superfamily Globotruncanoidea. However, they have an independent origin, probably from rugoglobigerinoids as Archaeoglobigerina Pessagno, 1967 (see Caron, 1985).

New superfamily Parvularugoglobigerinoidea and new family Parvularuglobigerinidae

In addition to proposing that Pseudocaucasina was the first Cenozoic globigerinid genus to appear, Arenillas and Arz (2017) were in favour of including this genus in a new ancestral Cenozoic family of the order Globigerinida together with Parvularugoglobigerina and Palaeoglobigerina Arenillas, Arz \& Náñez, 2007. Until now, these taxa have been informally termed parvularugoglobigerinids. They gather the tiny species with microperforate, smooth wall discovered by Luterbacher and Premoli-Silva (1964) immediately above the KPB (also see Arenillas \& Arz, 2000). We here group these primitive Cenozoic taxa into the new family Parvularuglobigerinidae, because Parvularugoglobigerina is the genus that best characterizes it. The parvularugoglobigerinids cannot be included in the family Eoglobigerinidae Blow, 1979, or in the family Globanomalinidae Loeblich \& Tappan, 1984, because they are the ancestral forms of both, and do not conform to the wall-texture characteristics of either of them (Figs. 3, 4). Consequently, it is also necessary to separate them into a new superfamily (Parvularuglobigerinoidea) to differentiate them from superfamilies Eoglobigerinoidea BouDagher-Fadel, 2012, and Globanomalinidoidea Loeblich \& Tappan, 1984.

\section{PLANKTIC FORAMINIFERAL SYSTEMATICS}

We follow Lee (1990) who raised the order Foraminiferida to class Foraminifera, and consequently the previously recognized suborder Globigerinina to order Globigerinida (Loeblich \& Tappan, 1992). A brief discussion on the higher-rank classification and phylogeny of foraminifera is presented in supplementary text S7. For each one of the taxa considered, we have added its type-taxon, its chronostratigraphic range, and lower rank taxa it includes. Only newly defined taxa and emended orders are described in their diagnosis section. We have also included the derivatio nominis of the defined taxa. 
Class FORAMINIFERA Lankester, 1885 Order GLOBOTRUNCANIDA Arz, Arenillas \& Gilabert n. ord.

Type-superfamily. Globotruncanidae Brotzen, 1942.

Derivatio nominis. As for the superfamily Globotruncanidae Brotzen, 1942.

Chronostratigraphic range. Bajocian-Maastrichtian.

Diagnosis. Test trochospiral or planispiral. Peripheral margin without keel, or with one or two keel. Aperture bordered by a lip or protected by a porticus or a tegillum, rarely by a bulla. Finely perforate to macroperforate. Wall surface smooth, pore-mounded, pitted, reticulate, hispid, pustulate, muricate, rugose, or costate. Wall hyaline calcitic, but early forms may be aragonitic.

Superfamilies included. Abathomphaloidea Arz, Arenillas \& Gilabert n. superfam.; Favuselloidea Longoria, 1974; Hedbergelloidea Longoria \& Gamper, 1975; Globotruncanoidea Brotzen, 1942; Planomalinoidea Bolli, Loeblich \& Tappan, 1957; Rotaliporoidea Sigal, 1958; Rugoglobigerinoidea Subbotina, 1959.

Superfamily ABATHOMPHALOIDEA Arz, Arenillas \& Gilabert n. superfam.

Type-family. Abathomphalidae Pessagno, 1967.

Derivatio nominis. As for the family Abathomphalidae Pessagno, 1967.

Chronostratigraphic range. Middle CampanianMaastrichtian.

Diagnosis. Test trochospiral. Peripheral margin without keel, with pustulate pseudo-keel or one or two keels. Aperture protected by a porticus or a tegillum. Macroperforate. Wall surface pustulate (muricate), rugose or discontinuous costate.

Families included. Abathomphalidae Pessagno, 1967; Globotruncanellidae Maslakova, 1964.

Family ABATHOMPHALIDAE Pessagno, 1967

Type-genus. Abathomphalus Bolli, Loeblich \& Tappan, 1957.

Chronostratigraphic range. Maastrichtian.

Genera included. Abathomphalus Bolli, Loeblich \& Tappan, 1957.

Family GLOBOTRUNCANELLIDAE Maslakova, 1964

Type-genus. Globotruncanella Reiss, 1957.

Chronostratigraphic range. Middle CampanianMaastrichtian.
Genera included. Globotruncanella Reiss, 1957; Spinoglobotruncanella Georgescu \& Sawyer, 2014.

Superfamily FAVUSELLOIDEA Longoria, 1974

Type-superfamily. Favusellidae Longoria, 1974.

Chronostratigraphic range. Bajocian-lower Cenomanian.

Families included. Conoglobigerinidae BouDagherFadel, Banner \& Whittaker, 1997; Favusellidae Longoria, 1974; Globuligerinidae Loeblich \& Tappan, 1984.

Family CONOGLOBIGERINIDAE BouDagher-Fadel, Banner \& Whittaker, 1997

Type-genus. Conoglobigerina Morozova, 1961, in Morozova and Moskalenko (1961).

Chronostratigraphic range. Bajocian-middle Valanginian.

Genera included. Conoglobigerina Morozova, 1961, in Morozova and Moskalenko (1961); Tenuigerina Gorbachik \& Kuznetsova, 1998.

Problematic taxa (other benthic origins). Sphaerogerina Korchagin \& Kuznetsova, 2003, in Korchagin et al. (2003) (Family Sphaerogerinidae BouDagher-Fadel, 2012).

Family FAVUSELLIDAE Longoria, 1974

Type-genus. Favusella Michael, 1973.

Chronostratigraphic range. Berriasian-lower Cenomanian.

Genera included. Ascoliella Banner \& Desai, 1988; Favusella Michael, 1973; Koutsoukosia Georgescu, 2009a.

Family GLOBULIGERINIDAE Loeblich \& Tappan, 1984

Type-genus. Globuligerina Bignot \& Guyader, 1971.

Chronostratigraphic range. Bathonian-middle Tithonian.

Genera included. Compactogerina Simmons, BouDagher-Fadel, Banner \& Whittaker, 1997, in BouDagher-Fadel et al. (1997); Globuligerina Bignot \& Guyader, 1971; Haeuslerina BouDagher-Fadel, Banner \& Whittaker, 1997; Petaloglobigerina Gradstein, 2021, in Gradstein and Waskowska (2021).

Superfamily HEDBERGELLOIDEA Longoria \& Gamper, 1975

Type-family. Hedbergellidae Loeblich \& Tappan, 1961.

Chronostratigraphic range. middle ValanginianMaastrichtian. 
Families included. Ananiidae El-Nakhal, 2010; Hedbergellidae Loeblich \& Tappan, 1961; Helvetoglobotruncanidae Lamolda, 1976; Praehedbergellidae Banner \& Desai 1988.

Family ANANIIDAE EI-Nakhal, 2010

Type-genus. Anania El-Nakhal, 2010.

Chronostratigraphic range. Middle Albian-Maastrichtian.

Genera included. Anania El-Nakhal, 2010; Badriella El-Nakhal, 2002; Costellagerina Petters, El-Nakhal \& Cifelli, 1983; Hillsella Georgescu, 2008a; Liuenella Georgescu, 2010c (new name for Liuella Georgescu, 2008b); LoeblichellaPessagno, 1967; Muricohedbergella Huber \& Leckie, 2011; Paracostellagerina Georgescu \& Huber, 2006; Pessagnoina Georgescu, 2009b; Planohedbergella BouDagher-Fadel, Banner, Whittaker \& McCarthy, 1997, in BouDagher-Fadel et al. (1997); Pseudoclavihedbergella Georgescu, 2009b.

Genus-level taxa defined as evolutionary lineages (without type species). Vanhintella Georgescu, 2013b.

Family HEDBERGELLIDAE Loeblich \& Tappan, 1961

Type-genus. Hedbergella Brönnimann \& Brown, 1958.

Chronostratigraphic range. Middle Aptian-Coniacian.

Genera included. Asterohedbergella Hamaoui, 1964; Clavihedbergella Banner \& Blow, 1959; Hedbergella Brönnimann \& Brown, 1958; Microhedbergella Huber \& Leckie, 2011; Paraticinella Premoli-Silva, Caron, Leckie, Petrizzo, Soldan \& Verga, 2009; Pseudoguembelitria Huber \& Leckie, 2011.

Family HELVETOGLOBOTRUNCANIDAE Lamolda, 1976

Type-genus. Helvetoglobotruncana Reiss, 1957.

Chronostratigraphic range. Lower Cenomanian-lower Campanian.

Genera included. Angulocarinella Korchagin, 2001; Bermudeziana Georgescu, 2011; Bollitruncana Korchagin, 2001; Fingeria Georgescu, 2010b; Hedbergellita Maslakova, 1983; Brittonella Korchagin, 1989; Helvetoglobotruncana Reiss, 1957; Unitruncatus Korchagin, 2001; Whiteinella Pessagno, 1967.

Family PRAEHEDBERGELLIDAE Banner \& Desai 1988

Type-genus. Praehedbergella Gorbachik \& Moullade, 1973.

Chronostratigraphic range. Middle Valanginian-Cenomanian.
Genera included. Blefuscuiana Banner \& Desai, 1988; Gorbachikella Banner \& Desai, 1988; Praehedbergella Gorbachik \& Moullade, 1973; Lilliputianella Banner \& Desai, 1988; Lilliputianelloides BouDagher-Fadel, Banner \& Whittaker, 1997; Wondersella Banner \& Strank, 1987.

Superfamily GLOBOTRUNCANOIDEA Brotzen, 1942

Type-family. Globotruncanidae Brotzen, 1942.

Chronostratigraphic range. Middle Albian-Maastrichtian.

Families included. Globotruncanidae Brotzen, 1942; Praeglobotruncanidae Ion, 1983; Reissidae Korchagin, 2001.

Family GLOBOTRUNCANIDAE Brotzen, 1942

Type-genus. Globotruncana Cushman, 1927.

Chronostratigraphic range. Middle Turonian-Maastrichtian.

Genera included. Contusotruncana Korchagin, 1982; Globotruncana Cushman, 1927; Marginotruncana Hofker, 1956; Obliquacarinata Korchagin, 1993; Sphaerotruncana Korchagin, 1993; Ventrotruncana Korchagin, 1993.

Family PRAEGLOBOTRUNCANIDAE Ion, 1983

Type-genus. Praeglobotruncana Bermúdez, 1952.

Chronostratigraphic range. Middle Albian-lower Campanian.

Genera included. Concavatotruncana Korchagin, 1982; Dicarinella Porthault, 1970, in Donze et al. (1970); Falsotruncana Caron, 1981; Rotundina Subbotina, 1953; Praeglobotruncana Bermúdez, 1952; Verotruncana Korchagin, 2001.

Genus-level taxa defined as evolutionary lineages (without type species). Exmouthia Georgescu, 2013, in Georgescu et al. (2013).

Family REISSIDAE Korchagin, 2001

Type-genus. Globotruncanita Reiss, 1957.

Chronostratigraphic range. Turonian-Maastrichtian.

Genera included. Elevatotruncana Korchagin, 2001; Globotruncanita Reiss, 1957; Kassabiana Salaj \& Solakius, 1984; Radotruncana El-Naggar, 1971; Sigalitruncana Korchagin, 1982; Turbotruncana Korchagin, 1993.

Superfamily PLANOMALINOIDEA Bolli, Loeblich \& Tappan, 1957 
Type-family. Planomalinidae Bolli, Loeblich \& Tappan, 1957.

Chronostratigraphic range. Middle Barremian-Maastrichtian.

Families included. Eohastigerinellidae Loeblich \& Tappan, 1984; Globigerinelloididae Longoria, 1974; Planomalinidae Bolli, Loeblich \& Tappan, 1957; Schackoinidae Pokorný, 1958.

Family EOHASTIGERINELLIDAE Loeblich \& Tappan, 1984

Type-genus. Eohastigerinella Morozova, 1957.

Chronostratigraphic range. Turonian-Santonian.

Genera included. Eohastigerinella Morozova, 1957; Hastigerinoides Brönnimann, 1952.

Family GLOBIGERINELLOIDIDAE Longoria, 1974

Type-genus. Globigerinelloides Cushman \& ten Dam, 1948.

Chronostratigraphic range. Middle Barremian-Maastrichtian.

Genera included. Alanlordella BouDagher-Fadel, 1995; Allotheca Ehrenberg, 1843; Biglobigerinella Lalicker, 1948; Blowiella Kretzchmar \& Gorbachik, 1971, in Gorbachik (1971); Claviblowiella BouDagher-Fadel Banner \& Whittaker, 1997; Globigerinelloides Cushman \& ten Dam, 1948; Pseudoschackoina Verga \& PremoliSilva, 2005.

Family PLANOMALINIDAE Bolli, Loeblich \& Tappan, 1957

Type-genus. Planomalina Loeblich \& Tappan, 1946.

Chronostratigraphic range. Middle Aptian-Cenomanian.

Genera included. Planomalina Loeblich \& Tappan, 1946;

Pseudoplanomalina Moullade, Bellier \& Tronchetti, 2002.

Genus-level taxa defined as evolutionary lineages (without type species). Bannerina Georgescu \& Sawyer, 2013, in Georgescu et al. (2013).

Family SCHACKOINIDAE Pokorný, 1958

Type-genus. Schackoina Thalmann, 1932.

Chronostratigraphic range. Aptian-Maastrichtian.

Genera included. Leupoldina Bolli, 1957; Schackoina Thalmann, 1932.

Genus-level taxa defined as evolutionary lineages (without type species). Asymetria Georgescu, 2012;
Groshenyia Georgescu, 2012; Neoschackoina Georgescu, 2012.

Superfamily ROTALIPOROIDEA Sigal, 1958

Type-family. Rotaliporidae Sigal, 1958.

Chronostratigraphic range. Albian-middle Turonian.

Families included. Rotaliporidae Sigal, 1958; Ticinellidae Longoria, 1974.

Family ROTALIPORIDAE Sigal, 1958

Type-genus. Rotalipora Brotzen, 1942.

Chronostratigraphic range. Middle Albian-middle Turonian.

Genera included. Anaticinella Eicher, 1973; Pseudothalmanninella Wonders, 1978; Rotalipora Brotzen, 1942; Thalmanninella Sigal, 1948.

Family TICINELLIDAE Longoria, 1974

Type-genus. Ticinella Reichel, 1950.

Chronostratigraphic range. Albian.

Genera included. Biticinella Sigal, 1956; Claviticinella El-Naggar, 1971; Ticinella Reichel, 1950.

Superfamily RUGOGLOBIGERINOIDEA Subbotina, 1959

Type-family. Rugoglobigerinidae Subbotina, 1959.

Chronostratigraphic range. Turonian-Maastrichtian.

Families included. Helvetiellidae Longoria \& Gamper, 1984; Rugoglobigerinidae Subbotina, 1959.

Family HELVETIELLIDAE Longoria \& Gamper, 1984

Type-genus. Helvetiella Longoria \& Gamper, 1984.

Chronostratigraphic range. Turonian-Maastrichtian.

Genera included. Archaeoglobigerina Pessagno, 1967; Bucherina Brönnimann \& Brown, 1956; Gansserina Robaszynski, Caron, González-Donoso, \& Wonders, 1984; Globocarinata Korchagin, 1993; Helvetiella Longoria \& Gamper, 1984; Kuglerina Brönnimann \& Brown, 1956.

Genus-level taxa defined as evolutionary lineages (without type species). Dorbignya Georgescu, 2013b; Gandolfia Georgescu, 2012; Edgarinella Georgescu, 2013b.

Family RUGOGLOBIGERINIDAE Subbotina, 1959

Type-genus. Rugoglobigerina Brönnimann, 1952. 
Chronostratigraphic range. Santonian-Maastrichtian.

Genera included. Archaeoglobitruncana Salaj \& Maamouri, 1984; Plummerita Brönnimann, 1952; Rugoglobigerina Brönnimann, 1952; Rugosocarinata Korchagin, 1993; Rugotruncana Brönnimann \& Brown, 1956; Trinitella Brönnimann, 1952.

Order GLOBIGERINIDA Lankester, 1885, emended

Type-superfamily. Globigerinoidea Carpenter, Parker \& Jones, 1862.

\section{Chronostratigraphic range. Danian-Recent.}

Emended Diagnosis. Test trochospiral or planispiral, or mixed trochospiral-planispiral, trochospiral-streptospiral and trochospiral-triserial. Peripheral margin without carinae, or with one carinae or muricocarinae. Aperture bordered by a lip or protected by a porticus, a tooth or a bulla. Microperforate to macroperforate. Wall surface smooth, pitted, cancellate, pustulate, muricate or spinose. Wall hyaline calcitic.

Superfamilies included. Parvularugoglobigerinoidea Arenillas, Arz \& Gilabertn. superfam.; Eoglobigerinoidea BouDagher-Fadel, 2012; Globigerinoidea Carpenter, Parker \& Jones, 1862; Globorotalioidea Cushman, 1927; Globanomalinidoidea Loeblich \& Tappan, 1984; Hantkeninoidea Cushman, 1927; Truncorotaloidinoidea BouDagher-Fadel, 2012.

Superfamily PARVULARUGOGLOBIGERINOIDEA Arenillas, Arz \& Gilabert n. superfam.

Type-family. Parvularuglobigerinidae Arenillas, Arz \& Gilabert n. fam.

Derivatio nominis. As for the family Parvularuglobigerinidae Arenillas, Arz \& Gilabert n. fam.

Chronostratigraphic range. Lowermost Danian.

Diagnosis. Test trochospiral, or mixed trochospiraltriserial. Microperforate to finely perforate. Wall surface smooth.

Families included. Parvularuglobigerinidae Arenillas, Arz \& Gilabert n. fam.

Family PARVULARUGLOBIGERINIDAE Arenillas, Arz \& Gilabert n. fam.

Type-genus. Parvularugoglobigerina Hofker, 1978.

Derivatio nominis. As for the genus Parvularugoglobigerina Hofker, 1978.

Chronostratigraphic range. Lowermost Danian.

Diagnosis. See superfamily Parvularugoglobigerinoidea Arenillas, Arz \& Gilabert n. superfam.
Genera included. Pseudocaucasina Arenillas \& Arz, 2016 in Arenillas \& Arz (2017); Palaeoglobigerina Arenillas, Arz \& Náñez, 2007; Parvularugoglobigerina Hofker, 1978.

Superfamily EOGLOBIGERINOIDEA BouDagherFadel, 2012

Type-family. Eoglobigerinidae Blow, 1979.

Chronostratigraphic range. Danian-Recent.

Families included. Eoglobigerinidae Blow, 1979; Globoquadrinidae Blow, 1979; Neoacarininidae BouDagher-Fadel, 2012; Porticulasphaeridae Banner, 1982.

Family EOGLOBIGERINIDAE Blow, 1979

Type-genus. Eoglobigerina Morozova, 1959.

Chronostratigraphic range. Danian-Langhian.

Genera included. Alicantina Soldan, Petrizzo \& Premoli-Silva, 2018; Eoclavatorella CremadesCampos, 1980; Eoglobigerina Morozova, 1959; Parasubbotina Olsson, Hemleben, Berggren \& Liu, 1992; Pseudoglobigerinella Olsson \& Pearson, 2006, in Olsson et al. (2006b); Subbotina Brotzen \& Pożaryska, 1961; Turbeogloborotalia BouDagher-Fadel, 2012.

Family GLOBOQUADRINIDAE Blow, 1979

Type-genus. Globoquadrina Finlay, 1947.

Chronostratigraphic range. Upper Ypresian-Recent.

Genera included. Dentoglobigerina Blow, 1979; Globoquadrina Finlay, 1947.

Family NEOACARININIDAE BouDagher-Fadel, 2012

Type-genus. Neoacarinina Thompson, 1973.

Chronostratigraphic range. Pleistocene.

Genera included. Neoacarinina Thompson, 1973.

Family PORTICULASPHAERIDAE Banner, 1982

Type-genus. Porticulasphaera Bolli, Loeblich \& Tappan, 1957.

Chronostratigraphic range. Middle Ypresian-Priabonian.

Genera included. Globigerinatheka Brönnimann, 1952; Guembelitrioides El-Naggar, 1971; Inordinatosphaera Mohan \& Soodan, 1967; Orbulinoides Cordey, 1968; Porticulasphaera Bolli, Loeblich \& Tappan, 1957.

Superfamily GLOBIGERINOIDEA Carpenter, Parker \& Jones, 1862 
Type-family. Globigerinidae Carpenter, Parker \& Jones, 1862.

Chronostratigraphic range. Lower Ypresian-Recent.

Families included. Globigerinidae Carpenter, Parker \& Jones, 1862; Globigerinellidae BouDagher-Fadel, 2012; Hastigerinidae Bolli, Loeblich \& Tappan, 1957; Orbulinidae Schultze, 1854; Sphaeroidinellidae Banner \& Blow, 1959; Turborotalitidae Hofker, 1976.

Family GLOBIGERINIDAE Carpenter, Parker \& Jones, 1862

Type-genus. Globigerina d'Orbigny, 1826, in Parker et al. (1865).

Chronostratigraphic range. Lower Ypresian-Recent.

Genera included. Alloglobigerinoides Huang, 1986; Ciperoella Olsson \& Hemleben, 2018, in Olsson et al. (2018); Globigerina d'Orbigny, 1826, in Parker et al. (1865); Globicuniculus Saito \& Thompson, 1976, in Saito et al. (1976); Globigerinoides Cushman, 1927; Globigerinoidesella El-Naggar, 1971; Globoturborotalita Hofker, 1976; Trilobigerina Popescu, 1987 (= Trilobatus Spezzaferri, Kucera, Pearson, Wade, Rappo, Poole, Morard \& Stalder, 2015); Zeaglobigerina Kennett \& Srinivasan, 1983.

Family GLOBIGERINELLIDAE BouDagher-Fadel, 2012

Type-genus. Globigerinella Cushman, 1927.

Chronostratigraphic range. Lower Rupelian-Recent.

Genera included. Beella Banner \& Blow, 1960; Bolliella Banner \& Blow, 1959; Globigerinella Cushman, 1927; Orcadia Boltovskoy \& Watanabe, 1982; Protentella Lipps, 1964; Quiltyella Coxall \& Spezzaferri, 2018, in Spezzaferri et al. (2018).

Family HASTIGERINIDAE Bolli, Loeblich \& Tappan, 1957

Type-genus. Hastigerina Thomson, 1876.

Chronostratigraphic range. Middle Tortonian-Recent.

Genera included. Hastigerina Thomson, 1876; Hastigerinella Cushman, 1927; Hastigerinopsis Saito \& Thompson, 1976, in Saito et al. (1976).

Family ORBULINIDAE Schultze, 1854

Type-genus. Orbulina d'Orbigny, 1839.

Chronostratigraphic range. Middle Burdigalian-Recent.

Genera included. Biorbulina Blow, 1956; Candorbulina Jedlitschka, 1934; Orbulina d'Orbigny, 1839; Praeorbulina Olsson, 1964.
Family SPHAEROIDINELLIDAE Banner \& Blow, 1959

Type-genus. Sphaeroidinella Cushman, 1927.

Chronostratigraphic range. Upper Aquitanian-Recent.

Genera included. Prosphaeroidinella Ujiié, 1976; Sphaeroidinella Cushman, 1927; Sphaeroidinellopsis Banner \& Blow, 1959.

Family TURBOROTALITIDAE Hofker, 1976

Type-genus. Turborotalita Blow \& Banner, 1962.

Chronostratigraphic range. Middle Lutecian-Recent.

Genera included. Berggrenia Parker, 1976; Turborotalita Blow \& Banner, 1962.

Superfamily GLOBOROTALIOIDEA Cushman, 1927

Type-family. Globorotaliidae Cushman, 1927.

Chronostratigraphic range. Ypresian-Recent.

Families included. Catapsydracidae Bolli, Loeblich \& Tappan, 1957; Globorotaloididae Banner \& Blow, 1959; Globorotaliidae Cushman, 1927; Pulleniatinidae Cushman, 1927.

Family CATAPSYDRACIDAE Bolli, Loeblich \& Tappan, 1957

Type-genus. Catapsydrax Bolli, Loeblich \& Tappan, 1957.

Chronostratigraphic range. Lower Ypresian-Bartonian.

Genera included. Catapsydrax Bolli, Loeblich \& Tappan, 1957; Globigerinopsoides Cita \& Mazzola, 1970; Globigerinoita Brönnimann, 1952; Velapertina Popescu, 1969.

Family GLOBOROTALOIDIDAE Banner \& Blow, 1959

Type-genus. Globorotaloides Bolli, 1957.

Chronostratigraphic range. Ypresian-Recent.

Genera included. Clavatorella Blow, 1965; Globorotaloides Bolli, 1957; Protentelloides Zhang \& Scott, 1995.

Family GLOBOROTALIIDAE Cushman, 1927

Type-genus. Globorotalia Cushman, 1927.

Chronostratigraphic range. Lower Ypresian-Recent.

Genera included. Dentigloborotalia Brummer, 1988; Fohsella Bandy, 1972; Globoconella Bandy, 1975; Globorotalia Cushman, 1927; Hirsutella Bandy, 1972; Jenkinsella Kennett \& Srinivasan, 1983; Menardella Bandy, 1972; Neogloboquadrina Bandy, Frerichs 
\& Vincent, 1967; Paragloborotalia Cifelli, 1982; Truncorotalia Cushman \& Bermúdez, 1949.

Family PULLENIATINIDAE Cushman, 1927

Type-genus. Pulleniatina Cushman, 1927.

Chronostratigraphic range. Messinian-Recent.

Genera included. Pulleniatina Cushman, 1927.

Superfamily GLOBANOMALINIDOIDEA Loeblich \& Tappan, 1984

Type-family. Globanomalinidae Loeblich \& Tappan, 1984.

Chronostratigraphic range. lower Danian-Rupelian.

Families included. Globanomalinidae Loeblich \& Tappan, 1984.

Family GLOBANOMALINIDAE Loeblich \& Tappan, 1984

Type-genus. Globanomalina Haque, 1956.

Chronostratigraphic range. Lower Danian-Rupelian.

Genera included. Carinoturborotalia BouDagher-Fadel, 2012; Globanomalina Haque, 1956; Luterbacheria Canudo, 1994; Planoglobanomalina Olsson \& Hemleben, 2006; Turborotalia Cushman \& Bermúdez, 1949.

Superfamily HANTKENINOIDEA Cushman, 1927

Type-family. Hantkeninidae Cushman, 1927.

Chronostratigraphic range. Lower Ypresian-middle Rupelian.

Families included. Pseudohastigerinidae Canudo, 1990; Hantkeninidae Cushman, 1927.

Family PSEUDOHASTIGERINIDAE Canudo, 1990

Type-genus. Pseudohastigerina Banner \& Blow, 1959.

Chronostratigraphic range. Lower Ypresian-middle Rupelian.

Genera included. Pseudohastigerina Banner \& Blow, 1959.

Family HANTKENINIDAE Cushman, 1927

Type-genus. Hantkenina Cushman, 1924.

Chronostratigraphic range. Middle Ypresian-Priabonian.

Genera included. Applinella Thalmann, 1942; Aragonella Thalmann, 1942; Clavigerinella Bolli, Loeblich
\& Tappan, 1957; Cribrohantkenina Thalmann, 1942; Hantkenina Cushman, 1924.

Superfamily TRUNCOROTALOIDINOIDEA BouDagher-Fadel, 2012

Type-family. Truncorotaloididae Loeblich \& Tappan, 1961.

Chronostratigraphic range. Lower Danian-lower Rupelian.

Families included. Globigerapsidae Blow, 1979; Planorotalitidae BouDagher-Fadel, 2012; Truncorotaloididae Loeblich \& Tappan, 1961.

Family GLOBIGERAPSIDAE Blow, 1979

Type-genus. Globigerapsis Bolli, Loeblich \& Tappan, 1957.

Chronostratigraphic range. Upper Selandian-upper Priabonian.

Genera included. Globigerapsis Bolli, Loeblich \& Tappan, 1957; Muricoglobigerina Blow, 1979.

Family PLANOROTALITIDAE BouDagher-Fadel, 2012

Type-genus. Planorotalites Morozova, 1957.

Chronostratigraphic range. Lower Ypresian-middle Bartonian.

Genera included. Astrorotalia Turnovsky, 1958; Planorotalites Morozova, 1957.

Family TRUNCOROTALOIDIDAE Loeblich \& Tappan, 1961.

Type-genus. Truncorotaloides Brönnimann \& Bermúdez, 1953.

Chronostratigraphic range. Lower Danian-lower Rupelian.

Genera included. Acarinina Subbotina, 1953; Igorina Davidzon, 1976; Morozovella McGowran, 1964; Morozovelloides Pearson \& Berggren, 2006; Pearsonites Soldan, Petrizzo \& Premoli-Silva, 2014; Praemurica Olsson, Hemleben, Berggren \& Liu, 1992; Pseudogloboquadrina Jenkins, 1966; Testacarinata Jenkins, 1971; Truncorotaloides Brönnimann \& Bermúdez, 1953.

Order HETEROHELICIDA Fursenko, 1958, emended Type-superfamily. Heterohelicoidea Cushman, 1927.

Chronostratigraphic range. Upper Albian-Maastrichtian.

Emended Diagnosis. Test biserial, or mixed planispiralbiserial, biserial-multiserial and biserial-uniserial. 
Microperforate to macroperforate. Wall surface smooth, pore-mounded, striate or costate. Wall hyaline calcitic.

Superfamilies included. Heterohelicoidea Cushman, 1927.

Superfamily HETEROHELICOIDEA Cushman, 1927

Type-family. Heterohelicidae Cushman, 1927.

Chronostratigraphic range. Upper Albian-Maastrichtian.

Families included. Gublerinidae Aliyulla, 1977; Heterohelicidae Cushman, 1927; Pseudotextulariidae Maamouri \& Salaj, 1978; Pseudoguembelinidae Aliyulla, 1977; Spiroplectidae Cushman, 1911; Ventilabrellidae Maamouri \& Salaj, 1978.

Family GUBLERINIDAE Aliyulla, 1977

Type-genus. Gublerina Kikoïne, 1948.

Chronostratigraphic range. Lower Campanian-Maastrichtian.

Genera included. Gublerina Kikoïne, 1948; Lipsonia Georgescu \& Abramovich, 2008a; Praegublerina Georgescu, Saupe \& Huber, 2008.

Family HETEROHELICIDAE Cushman, 1927

Type-genus. Heterohelix Ehrenberg, 1843.

Chronostratigraphic range. Upper Albian-Maastrichtian.

Genera included. Braunella Georgescu, 2007a; Bronnimannella Montanaro-Gallitelli, 1956; Globoheterohelix Georgescu \& Huber, 2009; Fleisherites Georgescu, 2009c; Hartella Georgescu \& Abramovich, 2009a; Heterohelix Ehrenberg, 1843; Huberella Georgescu, 2007b; Laeviheterohelix Nederbragt, 1991; Lunatriella Eicher \& Worstell, 1970a; Planoheterohelix Georgescu \& Huber, 2009; Protoheterohelix Georgescu \& Huber, 2009; Pseudoplanoglobulina Aliyulla, 1977; Steineckia Georgescu, 2009c; Striataella Aliyulla, 1977; Texasina Georgescu, 2010a.

Genus-level taxa defined as evolutionary lineages (without type species). Ehrenbergites Georgescu, 2013b; Lazarusina Georgescu, 2013b; Magellanina Georgescu, 2014a; Mihaia Georgescu, 2013, in Georgescu et al. (2013); Nederbragtina Georgescu, 2014a.

Problematic taxa (other benthic origins). Bifarina Parker \& Jones, 1872 (?family Gublerinidae); Rectoguembelina Cushman, 1932 (?family Gublerinidae); Zeauvigerina Finlay, 1939 (?family Eouvigerinidae Cushman, 1927, o family Loxostomatidae Loeblich \& Tappan, 1962).
Family PSEUDOTEXTULARIIDAE Maamouri \& Salaj, 1978.

Type-genus: Heterohelix Ehrenberg, 1843.

Chronostratigraphic range. Coniacian-Maastrichtian.

Genera included. Planoglobulina Cushman, 1927; Pseudotextularia Rzehak, 1891; Racemiguembelina Montanaro-Gallitelli, 1957.

Family PSEUDOGUEMBELINIDAE Aliyulla, 1977

Type-genus. Pseudoguembelina Brönnimann \& Brown, 1953.

Chronostratigraphic range. Lower Santonian-Maastrichtian.

Genera included. Leptobimodalia Georgescu, 2014a; Pseudoguembelina Brönnimann \& Brown, 1953.

Genus-level taxa defined as evolutionary lineages (without type species). Eicheriella Georgescu, 2014b.

Family SPIROPLECTIDAE Cushman, 1911

Type-genus. Spiroplecta Ehrenberg, 1844.

Chronostratigraphic range. Lower Santonian-Maastrichtian.

Genera included. Hendersonites Georgescu \& Abramovich, 2009b (new name for Hendersonia Georgescu \& Abramovich, 2008b); Paraspiroplecta Georgescu \& Abramovich, 2008b; Spiroplecta Ehrenberg, 1844.

Genus-level taxa defined as evolutionary lineages (without type species). Neohendersonites Georgescu, 2014c.

Family VENTILABRELLIDAE Maamouri \& Salaj, 1978

Type-genus. Ventilabrella Cushman, 1928.

Chronostratigraphic range. Santonian-Maastrichtian.

Genera included. Planulitella Georgescu, 2010a; Proliferania Georgescu, 2010a; Sigalia Reiss, 1957; Ventilabrella Cushman, 1928.

Order GUEMBELITRIIDA Arenillas, Arz \& Gilabert $n$. ord.

Type-superfamily. Guembelitrioidea MontanaroGallitelli, 1957.

Derivatio nominis. As for the superfamily Guembelitrioidea Montanaro-Gallitelli, 1957.

Chronostratigraphic range. Santonian-Serravallian.

Diagnosis. Test triserial, biserial, or trochospiral, or mixed triserial-biserial, triserial-trochospiral, or biserial- 
streptospiral. Microperforate to finely perforate. Wall surface smooth, pore-mounded, rugose, hispid or pustulate. Wall hyaline calcitic.

Superfamilies included. Cassigerinelloidea Bolli, Loeblich \& Tappan, 1957; Guembelitrioidea MontanaroGallitelli, 1957; Chiloguembelinoidea Reiss, 1963; Globoconusoidea BouDagher-Fadel, 2012.

Superfamily CASSIGERINELLOIDEA Bolli, Loeblich \& Tappan, 1957

Type-family. Cassigerinellidae Bolli, Loeblich \& Tappan, 1957.

Chronostratigraphic range. Bartonian-Serravallian.

Families included. Cassigerinellidae Bolli, Loeblich \& Tappan, 1957.

Family CASSIGERINELLIDAE Bolli, Loeblich \& Tappan, 1957

Type-genus. Cassigerinella Pokorný, 1955.

Chronostratigraphic range. Middle Bartonian-Serravallian.

Genera included. Cassigerinella Pokorný, 1955; Riveroinella Bermúdez \& Seiglie, 1967.

Superfamily GUEMBELITRIOIDEA MontanaroGallitelli, 1957

Type-family. Guembelitriidae Montanaro-Gallitelli, 1957.

Chronostratigraphic range. Santonian-lower Bartonian.

Families included. Guembelitriidae Montanaro-Gallitelli, 1957.

Family GUEMBELITRIIDAE Montanaro-Gallitelli, 1957

Type-genus. Guembelitria Cushman, 1933.

Chronostratigraphic range. Santonian-lower Bartonian.

Genera included. Cassigerinelloita Stolk, 1965; Guembelitria Cushman, 1933; Chiloguembelitria Hofker, 1978; Jenkinsina Haynes, 1981.

Problematic taxa (other benthic origins). Archaeoguembelitria Georgescu, 2009a (family Praeplanctonidae Georgescu, 2009a); Gallitellia Loeblich \& Tappan, 1986 (?family Stainforthiidae Reiss, 1963, or family Virgulinellidae Loeblich \& Tappan, 1984); Guembelitriella Tappan, 1940 (?family Turrilinidae Cushman, 1927).

Superfamily CHILOGUEMBELINOIDEA Reiss, 1963

Type-family. Chiloguembelinidae Reiss, 1963.
Chronostratigraphic range. Lowermost Danian-lower Rupelian.

Families included. Chiloguembelinidae Reiss, 1963.

Family CHILOGUEMBELINIDAE Loeblich \& Tappan, 1956

Type-genus. Chiloguembelina Loeblich \& Tappan, 1956.

Chronostratigraphic range. Lowermost Danian-lower Rupelian.

Genera included. Chiloguembelina Loeblich \& Tappan, 1956; Woodringina Loeblich \& Tappan, 1957.

Problematic taxa (other benthic origins). Streptochilus Brönnimann \& Resig, 1971 (family Bolivinidae Glaessner, 1937).

Superfamily GLOBOCONUSOIDEA BouDagher-Fadel, 2012

Type-family. Globoconusidae BouDagher-Fadel, 2012.

Chronostratigraphic range. Lowermost-upper Danian.

Families included. Globoconusidae BouDagher-Fadel, 2012.

Family GLOBOCONUSIDAE BouDagher-Fadel, 2012

Type-genus. Globoconusa Khalilov, 1956.

Chronostratigraphic range. Lowermost-upper Danian.

Genera included. Globoconusa Khalilov, 1956; Trochoguembelitria Arenillas, Arz \& Náñez, 2012.

Order? (unnamed)

Chronostratigraphic range. (middle Lutecian?) upper Bartonian-Recent.

Diagnosis. See Superfamily Globigerinitoidea BouDagher-Fadel, 2012, emended.

Superfamily GLOBIGERINITOIDEA BouDagher-Fadel, 2012, emended

Type-family. Globigerinitidae Bermúdez, 1961.

Chronostratigraphic range. (middle Lutecian?) upper Bartonian-Recent.

Emended Diagnosis. Tests trochospiral, or mixed triserial-trochospiral. Microperforate to finely perforate. Wall surface smooth, finely pustulate. Wall hyaline calcitic.

Families included. Candeinidae Cushman, 1927; Globigerinatellidae BouDagher-Fadel, 2012; Globigerinitidae Bermúdez, 1961; Tenuitellidae BouDagher-Fadel, 2012; Family? (unnamed). 
Family CANDEINIDAE Cushman, 1927

Type-genus. Candeina d'Orbigny, 1839.

Chronostratigraphic range. Tortonian-Recent.

Genera included. Candeina d'Orbigny, 1839.

Family GLOBIGERINATELLIDAE BouDagher-Fadel, 2012

Type-genus. Globigerinatella Cushman \& Stainforth, 1945.

Chronostratigraphic range. Upper Burdigalian-lower Langhian.

Genera included. Globigerinatella Cushman \& Stainforth, 1945.

Family GLOBIGERINITIDAE Bermúdez, 1961

Type-genus. Globigerinita Brönnimann, 1951.

Chronostratigraphic range. Chattian-Recent.

Genera included. Globigerinita Brönnimann, 1951; Mutabella Pearson, Norris \& Empson 2001; Polyperibola Liska, 1980; Tinophodella Loeblich \& Tappan, 1957.

Family TENUITELLIDAE BouDagher-Fadel, 2012

Type-genus. Tenuitella Fleisher, 1974.

Chronostratigraphic range. Upper Bartonian-Recent.

Genera included. Praetenuitella Li, 1987; Tenuitella Fleisher, 1974; Tenuitellinata Li, 1987; Tenuitellita Li, 1987.

Family ? (unnamed)

Genera included. Dipsidripella Brotea, 1995.

Chronostratigraphic range. Middle Lutecian-lower Rupelian.

Problematic taxa (other benthic origins). Antarcticella Loeblich \& Tappan, 1987 (?family Rotaliidae Ehrenberg, 1839.

Supplementary information. Supplementary material of this manuscript is available at the Spanish Journal of Palaeontology web-site (https://sepaleontologia.es/spanishjournal-palaeontology/) linked to the corresponding contribution. Supplementary Text S1: Clarification on the date of Loeblich \& Tappan (1987); Supplementary Text S2: Taxonomic notes on the order Globotruncanida; Supplementary Text S3: Taxonomic notes on the order Heterohelicida; Supplementary Text S4: Taxonomic notes on the order Guembelitriida; Supplementary Text S5: Taxonomic notes on the order Globigerinida; Supplementary Text S6: Taxonomic notes on the superfamily Globigerinitoidea; Supplementary Text S7: Higher-rank classification of planktic foraminifera.
Author contributions. IA, JAA and VG conceived the study, analysed the data, and wrote the manuscript.

Competing Interest. We declare no competing interests

Funding. This work was supported by MCIU/AEI/FEDER, UE (grant number PGC2018-093890-B-I00), and by the Aragonian Government/FEDER, UE (grant number DGA groups E33_17R and E33_20R).

Author details. Ignacio Arenillas, José Antonio Arz \& Vicente Gilabert. Departamento de Ciencias de la Tierra, and Instituto Universitario de Investigación en Ciencias Ambientales de Aragón, Universidad de Zaragoza, E-50009 Zaragoza, Spain; ias@unizar.es, josearz@unizar.es, vgilabert@unizar.es

Acnowledgements. We thank the Chief Editor, Carlos Martínez-Pérez, Associated Editors, Samuel Zamora and Sonia Ros-Franch, and the two reviewers, Juan Usera and an anonymous reviewer, for thoughtful and constructive reviews which improved the manuscript. This work was supported by the Ministerio de Ciencia, Innovación y Universidades (MCIU) / Agencia Estatal de Investigación (AEI) / Fondo Europeo de Desarrollo Regional (FEDER) (grant PGC2018093890-B-I00), and by the Aragonese Government / FEDER (grant DGA group E33_20R). V. Gilabert is supported by the Spanish Ministry of Economy and Competitiveness (MINECO) (FPI grant BES-2016-077800). The authors would like to acknowledge the use of the Servicio General de Apoyo a la Investigación-SAI, Universidad de Zaragoza.

\section{REFERENCES}

Abramovich, S., Yovel-Corem, S., Almogi-Labin, A., \& Benjamini, C. (2010). Global climate change and planktic foraminiferal response in the Maastrichtian. Paleoceanography, 25(2), PA2201. doi: 10.1029/ 2009PA001843

Aliyulla, Kh. (1977). Verkhniy Mel i rozvitie foraminifer Malogo Kavkaza (Azerbaydzhan) [Upper Cretaceous and development of Foraminifera of the Lesser Caucasus (Azerbaydzhan)]. Akademiya Nauk Azerbaydzhanskoy SSR, Institut Geologii Imeni Akademika I. M. Gubkina, Elm-Baku.

Alve, A. (1999). Colonization of new habitats by benthic foraminifera: a review. Earth-Science Reviews, 46, 167185. doi: 10.1016/S0012-8252(99)00016-1

Apellániz, E., Orue-Etxebarría, X., \& Luterbacher, H. P. (2002). Evolution of the early Paleocene planktonic foraminifera: A Basque point of view. Neues Jahrbuch für Geologie and Paläontologie, Abhundlungen, 225(2), 157-194. doi: 10.1127/njgpa/225/2002/157

Arenillas, I., \& Arz, J. A. (2000). Parvularugoglobigerina eugubina type-sample at Ceselli (Italy): planktic foraminiferal assemblage and lowermost Danian biostratigraphic implications. Rivista Italiana di Paleontologia e Stratigrafia, 106(3), 379-390. doi: 10.13130/2039-4942/6152

Arenillas, I., \& Arz, J. A. (2013a). Origin and evolution of the planktic foraminiferal Family Eoglobigerinidae Blow (1979) in the early Danian (Paleocene). Revista Mexicana de Ciencias Geológicas, 30(1), 159-177.

Arenillas, I., \& Arz, J. A. (2013b). New evidence on the origin of nonspinose pitted-cancellate species of the early Danian planktonic foraminifera. Geologica Carpathica, 64(3), 237-251. doi: 10.2478/geoca-2013-0016 
Arenillas, I., \& Arz, J. A. (2017). Benthic origin and earliest evolution of the first planktonic foraminifera after the Cretaceous/Paleogene boundary mass extinction. Historical Biology, 29(1), 17-24. doi: 10.1080/08912963.2015.1119133

Arenillas, I., Arz, J. A., \& Náñez, C. (2007). Morfología, Biometría y Taxonomía de foraminíferos planctónicos del Daniense basal: Palaeoglobigerina n. gen. Revista Española de Paleontología, 22(1), 21-62.

Arenillas, I., Arz, J. A., \& Náñez, C. (2012). Smooth and rugose wall textures in earliest Danian trochospiral planktic foraminifera from Tunisia. Neues Jahrbuch für Geologie und Paläontologie, Abhundlungen, 266(2), 123-142. doi: 10.1127/0077-7749/2012/0274

Arenillas, I., Arz, J. A., \& Náñez, C. (2016). New species of genus Trochoguembelitria from the lowermost Danian of Tunisia - biostratigraphic and evolutionary implications in planktonic foraminifera. Palaeontographica Abteilung $A$, 305(4-6), 133-160. doi: 10.1127/pala/305/2016/135

Arenillas, I., Arz, J. A., \& Gilabert, V. (2017). Revalidation of the genus Chiloguembelitria Hofker: implications for the evolution of early Danian planktonic foraminifera. Journal of African Earth Sciences, 134, 435-456. doi: 10.1016/j. jafrearsci.2017.07.01

Arenillas, I., Arz, J. A., \& Gilabert, V. (2018). Blooms of aberrant planktic foraminifera across the KPB in the Western Tethys: causes and evolutionary implications. Paleobiology, 44(3), 460-489. doi: 10.1017/pab.2018.16

Aurahs, R., Göker, M., Grimm, G., Hemleben, V., Hemleben, Ch., Schiebel, R., \& Kučera, M. (2009). Using the multiple analysis approach to reconstruct phylogenetic relationships among planktonic foraminifera from highly divergent and length-polymorphic SSU rDNA sequences. Bioinformatics and Biology Insights, 2003(3), 155-177. doi: $10.4137 /$ BBI.S3334

Aze, T., Ezard, T. H. G., Purvis, A., Coxall, H., Stewart, D., Wade, B., \& Pearson, P. (2011). A phylogeny of Cenozoic macroperforate planktonic foraminifera from fossil data. Biological Reviews, 86(4), 900-927. doi: 10.1111/j.1469185X.2011.00178

Bandy, O. L. (1967). Cretaceous planktonic foraminiferal zonation. Micropaleontology, 13(1), 1-31.

Bandy, O. L. (1972). Origin and development of Globorotalia (Turborotalia) pachyderma (Ehrenberg). Micropaleontology, 18(3), 294-318.

Bandy, O. L. (1975). Messinian evaporite deposition and the Miocene/Pliocene boundary, Pasquasia-Capodarso Sections in Sicily. In T. Saito, \& L. H. Burckel (Eds.), Late Neogene Epoch Boundaries. American Museum of Natural History, Micropaleontology Press, 1, 49-63.

Bandy, O. L., Frerichs, W. E., \& Vincent, E. (1967). Origin, development, and geologic significance of Neogloboquadrina Bandy, Frerichs, and Vincent, gen. nov. Contributions from the Cushman Foundation for Foraminiferal Research, 18, 152-157.

Banner, F. T. (1982). A classification and introduction to the Globigerinacea. In F. T. Banner, \& A. R. Lord (Eds.), Aspects of Micropalaeontology (pp. 141-239). George Alien \& Unwin.

Banner, F. T., \& Blow, W. H. (1959). The classification and stratigraphical distribution of the Globigerinaceae. Palaeontology, 1(2), 1-27.

Banner, F. T., \& Blow, W. H. (1960). The taxonomy, morphology and affinities of the genera included in the subfamily Hastigerininae. Micropaleontology, 6(1), 19-31.
Banner, F. T., \& Blow, W. H. (1965). Progress in the planktonic foraminiferal biostratigraphy of the Neogene. Nature, 208, 1164-1166. doi: 10.1038/2081164a0

Banner, F. T., \& Desai, D. (1988). A review and revision of the Jurassic-early Cretaceous Globigerinina, with especial reference to the Aptian assemblages of Speeton (North Yorkshire, England). Journal of Micropalaeontology, 7, 143-185. doi: 10.1144/jm.7.2.143

Banner, F. T, \& Strank, A. R. E. (1987). On Wondersella athersuchi, a new stratigraphically significant hedbergellid foraminifer from the Cretaceous Shuaiba Formation in the Middle East. Journal of Micropalaeontology, 6(1), 39-48. doi: 10.1144/jm.6.1.39

Banner, E. T., Pereira, C. P. G., \& Desai, D. (1985). "Tretomphaloid" float chambers in the Discorbidae and Cymbaloporidae. Journal of Foraminiferal Research, 15(3), 159-174. doi: 10.2113/gsjfr.15.3.159

Berggren, W. A. (1962). Stratigraphic and taxonomicphylogenetic studies of upper Cretaceous and Paleogene planktonic foraminifera. Stockholm Contributions in Geology, 9, 107-130.

Berggren, W. A. (1977). Atlas of Paleogene Planktonic Foraminifera. Some species of the genera Subbotina, Planorotalites, Morozovella, Acarinina and Truncorotaloides. In A. T. S. Ramsay (Ed.), Oceanic Micropaleontology (vol. 1, pp. 205-300). Academic Press.

Berggren, W. A., \& Norris, R. D. (1997). Biostratigraphy, phylogeny and systematics of Paleocene trochospiral planktic foraminifera. Micropaleontology, 43(1), 1-116.

Bermúdez, P. J. (1952). Estudio sistemático de los foraminíferos rotaliformes. Boletín de Geología, Venezuela, 2(4), 1-230.

Bermúdez, P. J. (1961). Contribución al estudio de las Globigerinidea de la región Caribe-Antillana (PaleocenoReciente). Memoria del III Congreso Geológico Venezolano, Caracas, Boletín de Geología, Publicación Especial, 3, 1119-1393.

Bermúdez, P. J., \& Seiglie, G. A. (1967). A new genus and species of foraminifer from the early Miocene of Puerto Rico. Tulane Studies in Geology and Paleontology, 5(3), 177-179.

Bernhard, J. M., Sen-Gupta, B. K., \& Borne, P. F. (1997). Benthic foraminiferal proxy to estimate dysoxic bottomwater oxygen concentration: Santa Barbara Basin, U.S. Pacific continental margin. Journal of Foraminiferal Research, 27(4), 301-310. doi: 10.2113/gsjfr.27.4.301

Bignot, G., \& Guyader, J. (1971). Observations nouvelles sur Globigerina oxfordiana Grigelis. In A. Farinacci (Ed.), Proceedings of the Second Planktonic Conference, Roma, 1970, 1, 79-81.

Blow, W. H. (1956). Origin and evolution of the foraminiferal genus Orbulina. Micropaleontology, 2(1), 57-70.

Blow, W. H. (1965). Clavatorella, a new genus of the Globorotaliidae. Micropaleontology, 11(3), 365-368.

Blow, W. H. (1979). The Cainozoic Globigerinidae. A study of the morphology, taxonomy, evolutionary relationship and the stratigraphical distribution of some Globigerinidae (mainly Globigerinacea). E. J. Brill.

Blow, W. H., \& Banner, F. T. (1962). The Mid-Tertiary (Upper Eocene to Aquitanian) Globigerinaceae. In F. E. Eames, F. T. Banner, W. H. Blow, \& W. J. Clarke (Eds.), Fundamentals of mid-Tertiary stratigraphical correlation (pp. 61-151). Cambridge University Press.

Boersma, A. (1984). Campanian through Paleocene paleotemperature and carbon isotope sequence and 
the Cretaceous-Tertiary boundary in the Atlantic Ocean. In W. A. Berggren, and J. A. van Couvering (Eds.), Catastrophes and Earth History (pp. 247-278). Princeton University Press.

Boersma, A., Shackleton, N. J., Hall, M., \& Given, Q. (1979). Carbon and Oxygen Isotope Variations at DSDP Site 384 (North Atlantic) and Some Paleotemperatures and Carbon Isotope Variations in the Atlantic Ocean. In B. E. Tycholke, P. R. Vogt et al. (Eds.), Initial Reports of the Deep Sea Drilling Project (pp. 695-717). U.S. Government Printing Office, 43.

Bolli, H. M. (1957). Planktonic Foraminifera from the Oligocene-Miocene Cipero and Lengua Formations of Trinidad, B.W.I. United States National Museum Bulletin, 215, 97-123.

Bolli, H. M., \& Saunders, J. B. (1985). Oligocene to Holocene low latitude planktic foraminifera. In: H. M. Bolli, J. B. Saunders, \& K. Perch-Nielsen (Eds.), Plankton Stratigraphy (pp. 155-262). Cambridge University Press.

Bolli, H. M., Loeblich, Jr., A. R., \& Tappan, H. (1957). Planktonic foraminiferal families Hantkeninidae, Orbulinidae, Globorotaliidae, and Globotruncanidae. United States National Museum Bulletin, 215, 3-50.

Bolli, H. M., Saunders, J. B., \& Perch-Nielsen, K. (1985). Plankton Stratigraphy. Cambridge University Press.

Boltovskoy, E., \& Watanabe, S. (1982). Orcadia, nuevo género de foraminíferos planctónicos antárticos. Revista Española de Micropaleontología, 14, 5-11.

BouDagher-Fadel, M. K. (1995). The planktonic foraminifera of the Early Cretaceous of Tunisia compared to those of western and central Tethys. Paleopelagos, 5, 137-160.

BouDagher-Fadel, M. K. (2012). Biostratigraphic and geological significance of planktonic foraminifera. Office of the Vice Provost Research (OVPR), University College (1st edition).

BouDagher-Fadel, M. K. (2015). Biostratigraphic and geological significance of planktonic foraminifera. Developments in Palaeontology \& Stratigraphy Book Series, Elsevier (updated 2nd edition).

BouDagher-Fadel, M. K., Banner, F. T., \& Whittaker, J. E. (1997). The early evolutionary history of planktonic foraminifera. British Micropalaeontological Society Publication Series, Chapman and Hall Publishers.

Brinkhuis, H., \& Zachariasse, W. J. (1988). Dinoflagellate cysts, sea level changes and planktonic foraminifers across the Cretaceous-Tertiary boundary at El Haria, Northwest Tunisia. Marine Micropaleontology, 13(2), 153-191. doi: 10.1016/0377-8398(88)90002-3

Brönnimann, P. (1951). Globigerinita naparimaensis n. gen., n. sp., from the Miocene of Trinidad, B.W.I. Contributions from the Cushman Foundation for Foraminiferal Research, 2(1), 16-18.

Brönnimann, P. (1952). Plummerita new name for Plummerella Brönnimann, 1952 (non Plummerella De Long, 1942). Contributions from the Cushman Foundation for Foraminiferal Research, 3(3-4), 146.

Brönnimann, P., \& Bermúdez, P. J. (1953). Truncorotaloides, a new foraminiferal genus from the Eocene of Trinidad, B.W.I. Journal of Paleontology, 27(6), 817-820.

Brönnimann, P., \& Brown, Jr., N. K. (1953). Observations on some planktonic Heterohelicidae from the Upper Cretaceous of Cuba. Contributions from the Cushman Foundation for Foraminiferal Research, 4(4), 150-156.

Brönnimann, P., \& Brown, Jr., N. K. (1956). Taxonomy of the Globotruncanidae. Eclogae geologicae Helvetiae, 48(2), 503-562.
Brönnimann, P., \& Brown, Jr., N. K. (1958). Hedbergella, a new name for a Cretaceous planktonic foraminiferal genus. Journal of the Washington Academy of Sciences, 48(1), 15-17.

Brönnimann, P., \& Resig, J. (1971). A Neogene globigerinacean biochronologic time-scale of the southwestern Pacific. In E. L. Winterer, W. R. Reidel, et al. (Eds.), Initial Reports Deep Sea Drilling Project, U.S. Government Printing Office, Washington, D.C., 7, 12351469.

Brotea, D. (1995). A new planktonic foraminifer in upper Eocene deposits from north Transylvania. Romanian Journal of Paleontology, 76, 31-33.

Brotzen, F. (1942). Die Foraminiferengattung Gavelinella nov. gen. und die Systematik der Rotaliiformes. Arsbok Sveriges Geologiska Undersökning, 36(8), 1-60.

Brotzen, F. (1948). The Swedish Paleocene and its foraminiferal fauna. Årsbok Sveriges Geologiska Undersökning, 42(2), 1-140.

Brotzen, F., \& Pożaryska, T. (1961). Foraminifères de Paléocène et de l'Eocène inférieur en Pologne septentrionale; remarques paléogeographiques. Revue de Micropaléontologie, 4(3), 155-166.

Brummer, G. J. A. (1988). Comparative ontogeny and species definition of planktonic foraminfers: A case study of Dentigloborotalia anfracta n. gen. In G. J. A. Brummer, \& D. Kroon (Eds.), Planktonic Foraminifers as Tracers of Ocean-Climate History (pp. 51-75). Free University Press.

Canudo, J. I. (1990). Los foraminíferos planctónicos del Paleoceno-Eoceno en el Prepirineo meridional y su comparación con la Cordillera Bética. (PhD Thesis, Universidad de Zaragoza, Spain).

Canudo, J. I. (1994). Luterbacheria: un nuevo género de foraminífero planctónico (Protozoa) del PaleocenoEoceno y sus relaciones filogenéticas. Revista Española de Micropaleontología, 26(2), 23-42.

Caron, M. (1981). Un nouveau genre de foraminifère planctonique du Crétacé: Falsotruncana nov. gen. Eclogae geologicae Helvetiae, 74(1), 65-73.

Caron, M. (1985). Cretaceous planktic foraminifera. In H. M. Bolli, J. B. Saunders, \& K. Perch-Nielsen (Eds.), Plankton Stratigraphy (pp. 17-86). Cambridge University Press.

Carpenter, W. B., Parker, W. K., \& Jones, T. R. (1862). Introduction to the study of the Foraminifera. Ray Society Publications and Robert Hardwicke.

Cifelli, R. (1982). Early occurrences and some phylogenetic implications of spiny, honeycomb textured planktonic foraminifera. Journal of Foraminiferal Research, 12(2), 105-115. doi: 10.2113/gsjfr.12.2.105

Cita, M. B., \& Mazzola, G. (1970). Globigerinopsoides gen. n. from the Miocene of Algeria. Rivista Italiana di Paleontologia e Stratigrafia, 76, 465-476.

Clemence, M.-E., \& von Hillebrandt, A. (2013). Chapter 1. Oberhauserellidae (Benthic Foraminifera) outbursts during the environmental perturbations at the TriassicJurassic boundary: Palaeoecological implications. Foraminifera: Classification, Biology, and Evolution. In M. D. Georgescu (Ed.), Earth Sciences in the 21st Century (pp. 1-20). Nova Publishers.

Cordey, W. G. (1968). Morphology and phylogeny of Orbulinoides beckmanni (Saito 1962). Palaeontology, 11(3), 371-375.

Costa, O. G. (1856). Paleontologia del Regno di Napoli. Parte II. Atti della Accademia Pontaniana, 7(2), 113-378. 
Cremades-Campos, J. (1980). Eoclavatorella; nuevo genero de foraminífero planctónico del Eoceno inferior. Cuadernos de Geología, Universidad de Granada, 11, 209-214.

Cushman, J. A. (1911). A monograph of the foraminifera of the North Pacific Ocean. Pt. 2. Textulariidae. Bulletin of the United States National Museum, 71(2), 1-108.

Cushman, J. A. (1924). A new genus of Eocene foraminifera. Proceedings of the United States National Museum, 66(30), 1-4.

Cushman, J. A. (1926). Eouvigerina a new genus from the Cretaceous. Contributions from the Cushman Laboratory for Foraminiferal Research, 2(1), 3-6.

Cushman, J. A. (1927). An outline of a reclassification of the foraminifera. Contributions from the Cushman Laboratory for Foraminiferal Research, 3(1), 1-105.

Cushman, J. A. (1928). Additional genera of the foraminifera. Contributions from the Cushman Foundation for Foraminiferal Research, 4(1), 1-8.

Cushman, J. A. (1932). Rectogümbelina, a New Genus from the Cretaceous. Contributions from the Cushman Foundation for Foraminiferal Research, 8(1), 18-23.

Cushman, J. A. (1933). Some new foraminiferal genera. Contributions from the Cushman Foundation for Foraminiferal Research, 9(2), 32-38.

Cushman, J. A., \& Bermúdez, P. J. (1949). Some Cuban species of Globorotalia. Contributions from the Cushman Foundation for Foraminiferal Research, 25(2), 26-45.

Cushman, J. A., \& ten Dam, A. (1948). Globigerinelloides, a new genus of the Globigerinidae. Contributions from the Cushman Foundation for Foraminiferal Research, 24(2), 42-44.

Cushman, J. A., \& Stainforth, R. M. (1945). The Foraminifera of the Cipero Marl Formation of Trinidad, British West Indies. Contributions from the Cushman Foundation for Foraminiferal Research, Special Publication, 14, 75 pp.

Cushman, J. A., \& Wickenden, R. T. D. (1928). A new foraminiferal genus from the Upper Cretaceous. Contributions from the Cushman Laboratory for Foraminiferal Research, 4(1), 12-13.

Darling, K. F., Wade, C. M., Kroon, D., \& Brown, A. J. L. (1997). Planktic foraminiferal molecular evolution and their polyphyletic origins from benthic taxa. Marine Micropaleontology, 30(4), 251-266. doi: 10.1016/S03778398(96)00057-6

Darling, K. F., Thomas, E., Kasemann, S. A., Seears, H. A., Smart, C. W., \& Wade, C. M. (2009). Surviving mass extinction by bridging the benthic/planktic divide. Proceedings of the National Academy of Sciences of the United States of America, 106(31), 12629-12633. doi: 10.1073/pnas.0902827106

Davidzon, R. M. (1976). Novyy paleogenovyy rod planktonnykh foraminifer [A new planktonic foraminiferal genus]. Trudy Vsesoyuznogo Nauchnoissledovatel'skogo Geologo-razvedochnogo Neftyanogo Instituta (VNIGRI), Tadzhiskoe Otdelenie, 183, 197-198. [in Russian]

De Vargas, C., Zaninetti, L., Hilbrecht, H., \& Pawlowski, J. (1997). Phylogeny and rates of molecular evolution of planktonic foraminifera: SSU rDNA sequences compared to the fossil record. Journal of Molecular Evolution, 45, 285-294. doi: 10.1007/PL00006232

D'Haenens, S., Bornemann, A., Roose, K., Claeys, P., \& Speijer, R. (2012). Stable isotope paleoecology $\left(\delta^{13} \mathrm{C}\right.$ and $\delta^{18} \mathrm{O}$ ) of early Eocene Zeauvigerina aegyptiaca from the North Atlantic (DSDP Site 401). Austrian Journal of Earth Sciences, 105(1), 179-188.
D'Hondt, S., \& Zachos, J. C. (1993). On stable isotopic variation and earliest Paleocene planktonic foraminifera. Paleoceanography, 8(4), 527-547. doi: 10.1029/93PA00952

Donze, P., Porthault, B., Thomel, G., \& de Villoutreys, O. (1970). Le Sénonien inférieur de Puget-Théniers (AlpsMaritimes) et sa microfaune. Geobios, 3(2), 41-106. doi: 10.1016/S0016-6995(70)80011-0

D'Orbigny, A. D. (1839). Foraminifères. In R. de La Sagra (Ed.), Histoire physique, politique at naturelle de l'lle de Cuba (pp. 1-224). Arthur Bertrand.

Dubicka, Z., \& Wierzbowski, H. (2019). Planktic propagules as a potential long-distance dispersal mechanism of Cretaceous serial rotaliid benthic foraminifera. Cretaceous Research, 100, 14-23. doi: 10.1016/j. cretres.2019.03.012

El-Naggar, Z. R. (1971). On the classification, evolution and stratigraphical distribution of the Globigerinacea. Proceedings of the Second International Conference on Planktonic Microfossils, Edizioni Tecnoscienza, Roma, 1970, 1, 421-476.

El-Nakhal, H. (2002). Classification of the meridionally costellate Cretaceous planktonic foraminifera. Journal of Micropalaeontology, 21(1), 1-8. doi: 10.1144/jm.21.1.1

El-Nakhal, H. (2010). Anania, a new Cretaceous planktonic foraminiferal genus with meridional rugosity. Revue de Paléobiologie, 29(2), 405-410.

Ehrenberg, C. G. (1839). Über die Bildung der Kreidefelsen und des Kreidemergels durch unsichtbare Organismen. Abhandlungen der Königlichen Akademie der Wissenschaften zu Berlin, Physikalische Klasse, 1838, 59-147.

Ehrenberg, C. G. (1843). Verbreitung und Einfluss des Mikroskopischen Lebens in Süd- und Nord-Amerika. Physikalische Abhandlungen der Königlichen Akademie der Wissenschaften zu Berlin, 1841, 291-446.

Ehrenberg, C. G. (1844). Eine Mittheilung über zwei neue Lager von Gebirgsmassen aus Infusorien als MeeresAbsatz in Nord-Amerika und eine Vergleichung derselben mit den organischen Kreide-Gebilden in Europa und Afrika. Bericht über die zu Bekanntmachung geeigneten Verhandlungen der Königlichen Preussischen Akademie der Wissenschaften zu Berlin, 57-98.

Ehrenberg, C. G. (1854). Mikrogeologie. Das Erden und Felsen schaffende Wirken des unsichtbar kleinen selbstständigen Lebens auf der Erde. Leopold Voss. doi: 10.5962/bhl.title.118752

Eicher, D. L. (1973). Phylogeny of the late Cenomanian planktonic foraminiferal Anaticinella multiloculata (Morrow). Journal of Foraminiferal Research, 2(4), 184190.

Eicher, D. L., \& Worstell, P. (1970a). Lunatriella, a Cretaceous heterohelicid foraminifer from the western interior of the United States. Micropaleontology, 16(1), 117-121. doi: 10.2307/1484852

Eicher D. L., \& Worstell, P. (1970b). Cenomanian and Turonian foraminifera from the Great Plains, United States. Micropaleontology, 16(3), 269-324. doi: $10.2307 / 1485079$

Finlay, H. J. (1939). New Zealand foraminifera: Key species in stratigraphy - no. 1. Transactions of the Royal Society of New Zealand, 68, 504-533.

Finlay, H. J. (1947). New Zealand Foraminifera; key species in stratigraphy. New Zealand Journal of Science and Technology, 28(5), 259-292. 
Fleisher, R. L. (1974). Cenozoic planktonic foraminifera and biostratigraphy, Arabian Sea Deep Sea Drilling Project, Leg 23A. In R. B. Whitmarsh, O. E. Weser, D. A. Ross, et al. (Eds.), Initial Reports of the Deep Sea Drilling Project, 23, 1001-1072.

Fordham, B. G. (1986). Miocene-Pleistocene planktic foraminifers from D. S. D. P. Sites 208 and 77, and phylogeny and classification of Cenozoic species. In B. G. Fordham (Ed.), Evolutionary Monographs. ANU Research Publications.

Fuchs, W. (1967). Über Ursprung und Phylogenie der Trias"Globigerinen" und die Bedeutung dieses Formenkreises für das echte Plankton. Verhandlungen der Geologischen Bundesanstalt, Wien, 1967, 135-176.

Fuchs, W. (1970). Eine alpine tiefliassische Foraminiferenfauna von Hernstein in Niederösterreich. Verhandlungen der Geologischen Bundesanstalt, Wien, 1970, 66-145.

Fuchs, W. (1973). Ein Beitrag zur Kenntnis der Jura"Globigerinen" und verwandter Formen an Hand polnischen Materials des Callovien und Oxfordien. Verhandlungen der Geologischen Bundesanstalt, Wien, 3, 445-487.

Fuchs, W. (1975). Detailuntersuchungen an Trias"Globigerinen" mit Hilfe eine Rastelektronenmikroskopes. Verhandlungen der Geologischen Bundesanstalt, 4, 235-246.

Fursenko, A. V. (1958). Osnovnye etapy razvitiya fauny foraminifer $v$ geologicheskom proshlom [The major stages of development of foraminiferal faunas in the geological past]. Trudy Instituta Geologischeskikh Nauk, Akademiia Nauk Belorrusskoi SSR, Minsk, 1, 10-29. [in Russian]

Gajewska, M., Dubicka, Z., \& Hart, M. B. (2021). Jurassic planktic foraminifera from the Polish Basin. Journal of Micropalaeontology, 40(1), 1-13. doi: 10.5194/jm-40-12021

Georgescu, M. D. (2007a). Taxonomic re-evaluation of the Late Cretaceous serial planktic foraminifer Gümbelina punctulata Cushman, 1938 and related species. Revista Española de Micropaleontología, 39(3), 1-14.

Georgescu, M. D. (2007b). A new planktonic heterohelicid foraminiferal genus from the Upper Cretaceous (Turonian). Micropaleontology, 53(3), 212-220.

Georgescu, M. D. (2008a). A new planktonic foraminiferal taxon of the Family Hedbergellidae Loeblich and Tappan 1961 from the Upper Cretaceous (Upper TuronianConiacian) of the Caribbean region. Israel Journal of Earth Sciences, 57(1), 55-63. doi: 10.1560/IJES.57.1.55

Georgescu, M. D. (2008b). A new planktonic foraminifer (family Hedbergellidae Loeblich and Tappan, 1961) from the lower Campanian sediments of the Falkland Plateau, South Atlantic Ocean (DSDP Site 511). Journal of Foraminiferal Research, 38(2), 157-161. doi: 10.2113/ gsjfr.38.2.157

Georgescu, M. D. (2009a). On the origins of Superfamily Heterohelicacea Cushman, 1927 and the polyphyletic nature of planktic foraminifera. Revista Española de Micropaleontología, 41(1-2), 107-144.

Georgescu, M. D. (2009b). Upper Albian-lower Turonian non-schackoinid planktic foraminifera with elongate chambers: morphology reevaluation, taxonomy and evolutionary classification. Revista Española de Micropaleontología, 41(3), 255-294.
Georgescu, M. D. (2009c). Taxonomic revision and evolutionary classification of the biserial Cretaceous planktic foraminiferal genus Laeviheterohelix Nederbragt, 1991. Revista Mexicana de Ciencias Geológicas, 26(2), 315-334.

Georgescu, M. D. (2010a). Origin, taxonomic revision and evolutionary classification of the late Coniacian-early Campanian (Late Cretaceous) planktic foraminifera with multichamber growth in the adult stage. Revista Española de Micropaleontología, 42(1), 59-118.

Georgescu, M. D. (2010b). Evolutionary classification of the Upper Cretaceous (Turonian-lower Campanian) planktic foraminifera with incipient meridional ornamentation. Journal of Micropaleontology, 29(2), 149-161. doi: 10.1144/0262-821X10-004

Georgescu, M. D. (2010c). Liuenella, new name for Liuella Georgescu, 2008. Journal of Foraminiferal Research, 40(2), 206. doi: 10.2113/gsjfr.40.2.206

Georgescu, M. D. (2011). Iterative evolution, taxonomic revision and evolutionary classification of the praeglobotruncanid planktic foraminifera, Cretaceous (late Albian-Santonian). Revista Española de Micropaleontología, 43(3), 173-207.

Georgescu, M. D. (2012). Morphology, taxonomy, stratigraphic distribution and evolutionary classification of the schackoinid planktic foraminifera (late AlbianMaastrichtian, Cretaceous). In D. R. Bailey, \& S. E. Howard (Eds.), Deep-sea marine biology, geology, and human impact (pp. 1-62). Nova Publishers.

Georgescu, M. D. (2013a). New advances in understanding the heterohelicid planktic foraminifer early evolution. Studia UBB Geologia, 58(2), 19-28. doi: 10.5038/19378602.58.2.3

Georgescu, M. D. (2013b). Revised evolutionary systematics of the Cretaceous planktic foraminifera described by C.G. Ehrenberg. Micropaleontology, 59(1), 1-48.

Georgescu, M. D. (2013c). Foraminifera. Aspects of Classification, Stratigraphy, Ecology and Evolution. Earth Sciences in the 21st Century, Life Sciences, Marine Biology, Nova Science Publishers.

Georgescu, M. D. (2014a). Chapter 3. New Late Cretaceous (Santonian-Maastrichtian) heterohelicid planktic foraminifera from the Pacific and Indian Oceans and their biostratigraphic and evolutionary significance. In M. D. Georgescu, \& C. M. Henderson (Eds.), Evolutionary classification and English-based nomenclature in Cretaceous planktic foraminifera (pp. 37-71). Earth Sciences in the 21st Century, Life Sciences, Marine Biology, Nova Science Publishers.

Georgescu, M. D. (2014b). Chapter 5. Evolution of central perforate plate in the new condensed lineage Eicheriella. In M. D. Georgescu, \& C. M. Henderson (Eds.), Evolutionary classification and English-based nomenclature in Cretaceous planktic foraminifera (pp. 93-100). Earth Sciences in the 21st Century, Life Sciences, Marine Biology, Nova Science Publishers.

Georgescu, M. D. (2014c). Chapter 7. Evolutionary classification and nomenclature of the Cretaceous planktic foraminifera with the chambers alternately added with respect to the test growth axis. In M. D. Georgescu, \& C. M. Henderson (Eds.), Evolutionary Classification and English-Based Nomenclature in Cretaceous Planktic Foraminifera (pp. 129-248). Earth Sciences in the 21st Century, Life Sciences, Marine Biology, Nova Science Publishers. 
Georgescu, M. D. (2015). Handbook of Late Cretaceous planktic foraminifera. Practical classification, biostratigraphy. Paleontology, Geosciences and Stratigraphy, Nova Science Publishers.

Georgescu, M. D., \& Abramovich, S. (2008a). A new serial Cretaceous planktic foraminifer (Family Heterohelicidae Cushman, 1927) from the Upper Maastrichtian of the equatorial Central Pacific. Journal of Micropalaeontology, 27(2), 117-123. doi: 10.1144/jm.27.2.117

Georgescu, M. D., \& Abramovich, S. (2008b). Taxonomic revision and phylogenetic classification of the Late Cretaceous (Upper Santonian-Maastrichtian) serial planktonic foraminifera (Family Heterohelicidae Cushman, 1927) with peripheral test wall flexure. Revista Española de Micropaleontología, 40(1-2), 97-114.

Georgescu, M. D., \& Abramovich, S. (2009a). A new Late Cretaceous (Maastrichtian) serial planktic foraminifer (Family Heterohelicidae) with early planispiral coil and revision of Spiroplecta Ehrenberg, 1844. Geobios, 42(6), 687-698. doi: 10.1016/j.geobios.2009.06.001

Georgescu, M. D., \& Abramovich, S. (2009b). Short nomenclature note: A new name for the Upper Cretaceous planktic foraminiferal genus Hendersonia Georgescu and Abramovich, 2008. Revista Española de Micropaleontología, 41(1-2), 215.

Georgescu, M. D., \& Huber, B. T. (2009). Early evolution of the Cretaceous serial planktic foraminifera (late AlbianCenomanian). Journal of Foraminiferal Research, 39(4), 335-360. doi: 10.2113/gsjfr.39.4.335

Georgescu, M. D., \& Henderson, C. M. (2014). Evolutionary classification and english-based nomenclature in Cretaceous planktic foraminifera. Earth Sciences in the 21st Century, Life Sciences, Marine Biology, Nova Science Publishers.

Georgescu, M. D., \& Sawyer, M. S. (2014). Capítulo V: Evolutionary classification of the globotruncanellid annd abathomphalid planktic foraminifera (Late Cretaceous, Late Campanian-Maastrichtian). In M. D. Georgescu (Ed.), Foraminifera. Aspects of Classification, Stratigraphy, Ecology and Evolution (pp. 119-162). Nova Science Publishers.

Georgescu, M. D., Saupe, E. E., \& Huber, B. T. (2008). Morphometric and stratophenetic basis for phylogeny and taxonomy in Late Cretaceous gublerinid planktonic foraminifera. Micropaleontology, 54(5), 397-424.

Georgescu, M. D., Arz, J. A., Macauley, R. V., Kukulski, R. B., Arenillas, I., \& Pérez-Rodríguez, I. (2011). Late Cretaceous (late Santonian-Maastrichtian) serial planktic and benthic foraminifera with pore mounds or pore moundbased ornamentation structures. Revista Española de Micropaleontología, 43(1-2), 109-139.

Georgescu, M. D., Sawyer, M. S., Heikkinen, C. J., Burke, R. M. (2013). Chapter III: New and revised Cretaceous (Albian-Campanian) planktic foraminifera of the Atlantic, Indian and Pacific Oceans. In M. D. Georgescu (Ed.), Foraminifera. Aspects of Classification, Stratigraphy, Ecology and Evolution (pp. 59-100). Nova Science Publishers.

Georgescu, M. D., Burke, R. M., \& Heikkinen, C. J. (2014). Chapter 1. New data and insights on the polyphyletic origin of the Cretaceous planktic foraminifera. In: M. D. Georgescu, \& C. M. Henderson (Eds.), Evolutionary classification and english-based nomenclature in Cretaceous planktic foraminifera (pp. 3-25). Earth Sciences in the 21st Century, Life Sciences, Marine Biology, Nova Science Publishers.
Glaessner, M. F. (1937). Studien über foraminiferen aus der kreide und dem Tertiär des Kaukasus. I. Die foraminiferen der ältesten Tertiärschichten des Nordwest-Kaukasus. Problemy Paleontologii, Paleontologicheskay Laboratoriya Moskovskogo Universiteta, 2-3, 349-410.

Gorbachik, T. N. (1971). O rannemelovykh foraminiferakh Kryma [On early Cretaceous foraminifera from the Crimea]. Voprosy Mikropaleontologii, 14, 125-39. [in Russian]

Gorbachik, T. N., \& Kuznetsova, K. I. (1986). Izucheniye mineral'nogo sostava rakovin planktonnykh foraminifer [Study of mineral composition of shells of planktonic foraminifera]. Voprosy Mikropaleontologii, 28, 42-44. [in Russian]

Gorbachik, T. N., \& Kuznetsova, K. I. (1998). Voprosy sistematiki i nomenklatury rannego planktona (foraminifery) [Problems on the systematics and nomenclature of the early plankton (foraminifers)]. Paleontologicheskii Zhurnal, 32, 9-11. [in Russian]

Gorbachik, T. N., \& Moullade, M. (1973). Caractères microstructuraux de le parvis du test des foraminifères planctoniques du Cretace inferieur et leur signification sur le plan taxonomique. Compte Rendu Hebdomadaire des Séances de l'Académie des Sciences, Paris, series D, 277, 2661-2664.

Gordon, W. A. (1970). Biogeography of Jurassic Foraminifera. Geological Society of America Bulletin, 81(6), 16891704. doi: 10.1130/0016-7606(1970)81[1689:BOJF] 2.0.CO;2

Gradstein, F., \& Waskowska, A. (2021). New insights into the taxonomy and evolution of Jurassic planktonic foraminifera. Swiss Journal of Palaeontology, 140(1), 1-12. doi: 10.1186/s13358-020-00214-8

Gradstein, F., Gale, A., Kopaevich, L., Waskowska, A., Grigelis, A., Glinskikh, L., \& Görög, Á. (2017). The planktonic foraminifera of the Jurassic, Part II: Stratigraphy, palaeoecology and palaeobiogeography. Swiss Journal of Palaeontology, 136(2), 259-271. doi: 10.1007/s13358017-0132-y

Hamaoui, M. (1964). On a new subgenus of Hedbergella (Foraminiferida). Israel Joumal of Earth Sciences, 13(34), 133-142.

Haque, A. F. M. M. (1956). The Foraminifera of the Ranikot and the Laki of the Nammal Gorge, Salt Range. Paleontologica Pakistanica, Geological Survey of Pakistan, 1, 1-300.

Hart, M. B., Oxford, M. J., \& Hudson, W. (2002). The early evolution and palaeobiogeography of Mesozoic planktonic foraminifera. In J. A. Crame, \& A. W. Owen (Eds.), Palaeobiogeography and Biodiversity Change: the Ordovician and Mesozoic-Cenozoic Radiations. Geological Society, London, Special Publications, 194, 115-125. doi: 10.1144/GSL.SP.2002.194.01.09

Hart, M. B., Hylton, M. D., Oxford, M. J., Price, G. D., Hudson, W., \& Smart, C. W. (2003). The search for the origin of the planktic Foraminifera. Journal of the Geological Society, London, 160(3), 341-343. doi: 10.1144/0016-764903-003

Haynes, J. R. (1981). Foraminifera. John Wiley and Sons, A Halsted Press Book.

Hemleben, Ch., Spindler, M. \& Anderson, O. R. (1989). Modern Planktonic foraminifera. Springer-Verlag.

Hofker, J. (1953). Types of genera described in Part III of the "Siboga Foraminifera". The Micropaleontologist, 7(1), 26-28.

Hofker, J. (1956). Die Globotruncanen von Nordwest-Deutschland und Holland. Neues Jahrbuch für Geologie and Paläontologie, Abhandlungen, 103(3), 312-340. 
Hofker, J. (1976). La famille Turborotalitidae. Revue de Micropaléontologie, 19, 47-53.

Hofker, J. (1978). Analysis of a large succession of samples through the Upper Maastrichtian and the Lower Tertiary od Drill Hole 47.2, Shatsky Rise, Pacific, Deep Sea Drilling Project. Journal of Foraminiferal Research, 8(1), 46-75. doi: 10.2113/gsjfr.8.1.46

Holzmann, M., \& Pawlowski, J. (2017). An updated classification of rotaliid foraminifera based on ribosomal DNA phylogeny. Marine Micropaleontology, 132(1), 18-34. doi: 10.1016/j.marmicro.2017.04.002

Huang, T. Y. (1986). Alloglobigerinoides, a new planktic foraminiferal genus. Petroleum Geology of Taiwan, 22, 9-102.

Huber, B. T., \& Boersma, A. (1994). Cretaceous origination of Zeauvigerina and its relationship to Paleocene biserial planktonic foraminifera. Journal of Foraminiferal Research, 24(4), 268-287. doi: 10.2113/gsjfr.24.4.268

Huber, B. T., \& Leckie, R. M. (2011). Planktic foraminiferal species turnover across deep-sea Aptian/Albian boundary sections. Journal of Foraminiferal Research, 41(1), 53-95. doi: 10.2113/gsjfr.41.1.53

Huber, B. T., Olsson, R. K., \& Pearson, P. N. (2006). Chapter 16: Taxonomy, biostratigraphy, and phylogeny of Eocene microperforate planktonic foraminifera (Jenkinsina, Cassigerinelloita, Chiloguembelina, Streptochilus, Zeauvigerina, Tenuitella, and Cassigerinella) and Problematica (Dipsidripella). In P. N. Pearson, R. K. Olsson, B. T. Huber, Ch. Hemleben, \& W. A. Berggren (Eds.), Atlas of Eocene planktonic foraminifera. Cushman Foundation for Foraminiferal Research Special Publication, 41, 461-508.

Huber, B. T., Petrizzo, M. R., \& Macleod, K. G. (2020). Planktonic foraminiferal endemism at southern high latitudes following the terminal Cretaceous extinction. Journal of Foraminiferal Research, 50(4), 382-402. doi: 10.1130/abs/2020AM-352478

Hudson, W., Hart, M. B., \& Smart, C. W. (2009). Palaeobiogeography of early planktonic foraminifera. Bulletin de la Société Géologique de France, 180(1), 27-38. doi: 10.2113/gssgfbull.180.1.27

Ion, J. (1983). Étude micropaléontologique (Foraminifères planctoniques) du Crétacé Supérieur de Tara Bîrsei (Carpates Orientales). Memorii Institutul de Geologie si Geofizica Bucarest, 31, 5-176.

Jedlitschka, H. (1934). Über Candorbulina, eine neue Foramimferen-Gattung, und zwei neue Candeina-Arten. Verhandlungen des Naturforschenden Vereins in Brünn, 65, 17-26.

Jenkins, D. G. (1966). Planktonic foraminiferal zones and new taxa from the Danian to Lower Miocene of New Zealand. New Zealand Journal of Geololgy and Geophysics, 8(12), 1088-1126. doi: 10.1080/00288306.1965.10428156

Jenkins, D. G. (1971). New Zealand Planktonic Foraminifera. New Zealand Geological Survey, Paleontological Bulletin, 42, 1-278.

Keller, G., \& Pardo, A. (2004). Disaster opportunists Guembelitrinidae: index for environmental catastrophes. Marine Micropaleontology, 53(1), 83-116. doi: 10.1016/j. marmicro.2004.04.012

Kendall, S., Gradstein, F., Jones, C., Lord, O. T., \& Schmid, D. N. (2020). Ontogenetic disparity in early planktic foraminifers. Journal of Micropalaeontology, 39(1), 27-39. doi: 10.5194/jm-39-27-2020

Kennett, J. P., \& Srinivasan, M. S. (1983). Neogene Planktonic Foraminifera. Hutchinson Ross Publishing Co.
Khalilov, D. M. (1951). O faune foraminifer i raschlenenii Oligotsenovykh otlozheniy severo-vostochnogo predgorya Malogo Kavkaza [About the fauna of foraminifera and the division of Oligocene deposits of the northeastern foothills of the Lesser Caucasus]. Izvestiya Akademii Nauk Azerbaidzhanskoi SSR, 3, 43-61.

Khalilov, D. M. (1956). O pelagicheskoy faune foraminifer Paleogenovykh otlozheniy Azerbaydzhana [Pelagic Foraminifera of the Paleogene Deposits of the Azerbaizhan SSR]. Trudy Instituta Geologii, Akademiya Nauk Azerbaidzhanskoi SSR, 17, 234-255. [in Russian]

Kikoïne, J. (1948). Les Heterohelicidae du Crétacé Supérieur Pyrénéen. Bulletin de la Société Géologique de France, series 5, 18, 15-35.

Korchagin, O. A. (2001). K klassifikatsii Globotruncanidae Brotzen, 1942 [To Classification of Globotruncanidae Brotzen, 1942]. Geologiâ i Razvedka, 2, 17-22. [in Russian]

Korchagin, O. A. (2003). Klassifikatsiya mezozoiskikh planktonnykh foraminifer (nadsemeystva Planomalinacea, Rotaliporacea i Globotruncanacea) [Classification of the Mesozoic planktonic foraminifers (superfamilies Planomalinacea, Rotaliporacea, and Globotruncanacea)]. Trudy Geologicheskii Instituta, Rossiyskaya Akademiia Nauk, Moscow GEOS. [in Russian]

Korchagin, O. A., Kuznetsova, K. I., \& Bragin, N. Yu. (2003). Find of Early Planktonic Foraminifers in the Triassic of the Crimea. Doklady Earth Science, 390(4), 482-486 [Original in Russian, translated into English from Doklady Akademii Nauk, 390(1), 79-84].

Korchagin, V. I. (1982). Sistematika Globotrunkanid [Systematics of the Globotruncanids]. Byulletin Moskovskogo Obshchestva Ispytateley Prirody, Otdel Geologichskii, 57(5), 114-121. [in Russian]

Korchagin, V. I. (1989). Brittonella - novyy rod planktonnykh foraminifer [Brittonella - a new genus of planktonic foraminifera]. Doklady Akademiya Nauk Tadzhikskoi SSR, 31(9), 629-632. [in Russian]

Korchagin, V. I. (1993). Nekotoryye novyye rody i vidy planktonnykh foraminifer iz verkhnemelovykh otlozheniy Sredney Azii i Zapadnogo Kazakhstana [Some new genera and species of planktonic foraminifera from the Late Cretaceous of Central Asia and western Kazakhstan]. Paleontologicheskii metod $v$ geologii, Moscow: Institut Geologii i Razrabotki Goryuchikh Iskopaemykh (IGiRGI), 6, 114-136. [in Russian]

Koutsoukos, E. A. (2014). Phenotypic plasticity, speciations, and phylogeny in Early Danian planktic foraminifera. Journal of Foraminiferal Research, 44(2), 109-142. doi: 10.2113/gsjfr.44.2.109

Koutsoukos, E. A., \& Hart, M. B. (1990). Cretaceous foraminiferal morphogroup distribution patterns, palaeocommunities and trophic structures: a case study from the Sergipe Basin, Brazil. Transactions of the Royal Society of Edinburgh Earth Sciences, 81(3), 221-246. doi: 10.1017/S0263593300005253

Kroon, D., \& Nederbragt, A. J. (1990). Ecology and paleoecology of triserial planktic foraminifera. Marine Micropaleontology, 16(1-2), 25-38. doi: 10.1016/03778398(90)90027-J

Kucera, M., Silye, L., Weiner, A. K. M., Darling, K., Lübben, B., Holzmann, M., Pawlowski, J., Schönfeld, J., \& Morard, R. (2017). Caught in the act: anatomy of an ongoing benthic-planktonic transition in a marine protist. 
Journal of Plankton Research, 39(3), 1-14. doi: 10.1093/ plankt/fbx018

Lalicker, C. G. (1948). A new genus of foraminifera from the Upper Cretaceous. Journal of Paleontology, 22(5), 624.

Lamolda, M. A. (1976). Helvetoglobotruncaninae subfam. nov. y consideraciones sobre los globigeriniformes del Cretácico. Revista Española Micropaleontología, 8, 395-400.

Lankester, E. R. (1885). Protozoa. In T. S. Baynes (Ed.), The Encyclopedia Britannica (pp. 830-866), 9th Edition, 19. J. M. Stoddard Co.

Leckie, R. M. (1987). Paleoecology of Mid-Cretaceous planktonic foraminifera: a comparison of open ocean and epicontinental sea assemblages. Micropaleontology, 33(2), 164-176. doi: 10.2307/1485491

Leckie, R. M. (2009). Seeking a better life in the plankton. Proceedings of the National Academy of Sciences of the United States of America, 106(34), 14183-14184. doi: 10.1073/pnas.0907091106

Leckie, R. M., \& Webb, P. N. (1985). Candeina antarctica, n. sp. and the phylogenetic history and distribution of Candeina spp. in the Paleogene-early Neogene of the Southern Ocean. Journal of Foraminiferal Research, 15(2), 65-78.

Li, Q. (1986). Ultrastructure, morphology, affinities and reclassification of Cassigerinella Pokorny (Foraminiferida: Globigerinina). Journal of Micropalaeontology, 5(2), 49-64. doi: 10.1144/jm.5.2.49

Li, Q. (1987). Origin, phylogenetic development and systematic taxonomy of the Tenuitella plexus (Globigerinitidae, Globigerininina). Journal of Foraminiferal Research, 17(4), 298-320. doi: 10.2113/gsjfr.17.4.298

Li, Q., \& Radford, S. S. (1991). Evolution and biogeography of Paleogene microperforate planktonic foraminifera. Palaeogeography, Palaeoclimatology, Palaeoecology, 83(1-3), 87-115. doi: 10.1016/0031-0182(91)90077-5

Li, Q., McGowran, B., \& Boersma, A. (1995). Early Paleocene Parvularugoglobigerina and late Eocene Praetenuitella: does evolutionary convergence imply similar habitat? Journal of Micropaleontology, 14(2), 119-134. doi: org/10.1144/jm.14.2.119

Lipps, J. H. (1964). Miocene planktonic Foraminifera from Newport Bay, California. Tulane Studies in Geology, 2(4), 109-133.

Liska, R. D. (1980). Polyperibola, a new planktonic foraminiferal genus from the Late Miocene of Trinidad and Tobago. Journal of Foraminiferal Research, 10(2), 136-142. doi: 10.2113/gsjfr.10.2.136

Liu, C., \& Olsson, R. K. (1992). Evolutionary radiation of microperforate planktonic foraminifera following the $\mathrm{K} / \mathrm{T}$ mass extinction event. Journal of Foraminiferal Research, 22(4), 328-346. doi: 10.2113/gsjfr.22.4.328

Liu, C., \& Olsson, R. K. (1994). On the origin of Danian normal perforate planktonic foraminifera from Hedbergella. Journal of Foraminiferal Research, 24(2), 61-74. doi: 10.2113/gsjfr.24.2.61

Liu, C., Olsson, R. K., \& Huber, B. T. (1998). A benthic paleohabitat for Praepararotalia gen. nov. and Antarcticella Loeblich and Tappan. Journal of Foraminiferal Research, 28(1), 3-18.

Loeblich, Jr., A. R. (1957). Studies in Foraminifera. Bulletin of the United States National Museum, 215, 1-323.

Loeblich, Jr., A. R., \& Tappan, H. (1946). New Washita foraminifera. Journal of Paleontology, 20(3), 238-258.
Loeblich, Jr., A. R., \& Tappan, H. (1956). Chiloguembelina, a new Tertiary genus of the Heterohelicidae (Foraminifera). Journal of the Washington Academy of Sciences, 46(11), 340.

Loeblich, Jr., A. R., \& Tappan, H. (1957). The new planktonic foraminiferal genus Tinophodella, and an emendation of Globigerinita Brönnimann. Journal of the Washington Academy of Sciences, 47(4), 112-116.

Loeblich, Jr., A. R., \& Tappan, H. (1961). Cretaceous planktonic foraminifera: Part I-Cenomanian. Micropaleontology, 7(3), 257-304. doi: 10.2307/1484364

Loeblich, Jr., A. R., \& Tappan, H. (1962). Six new generic names in the Mycetozoida (Trichiidae) and Foraminiferida (Fischerinidae, Buliminidae, Caucasinidae and Pleurostomellidae) and a re-description of Loxostomum (Loxostomidae, new family). Proceedings of the Biological Society of Washington, 75, 107-113.

Loeblich, Jr., A. R., \& Tappan, H. (1964). Protista 2, part C, Sarcodina, chiefly "Thecamoebians" and Foraminiferida. In R. C. Moore (Ed.), Treatise on Invertebrate Paleontology. Geological Society of America and University of Kansas Press, Lawrence.

Loeblich, Jr., A. R., \& Tappan, H. (1984). Suprageneric classification of the Foraminiferida (Protozoa). Micropaleontology, 30(1), 1-70.

Loeblich, Jr., A. R., \& Tappan, H. (1986). Some new and revised genera and families or hyaline calcareous Foraminiferida (Protozoa). Transaction of the American Microscopical Society, 105(3), 219-265.

Loeblich, Jr., A. R., \& Tappan, H. (1987). Foraminiferal general and their classification. Van Nostrand Reinhold Company.

Loeblich, Jr., A. R. \& Tappan, H. (1992). Present Status of Foraminiferal Classification. Studies in Benthic Foraminifera, Benthos'90 (pp. 93-102), Sendai (1990), Tokai University Press.

Longoria, J. F. (1974). Stratigraphic, morphologic and taxonomic studies of Aptian planktonic Foraminifera. Revista Española de Micropaleontología, $n^{\circ}$ extraordinario, $1-107$.

Longoria, J. F., \& Gamper, M. A. (1975). The classification and evolution of Cretaceous planktonic foraminifera. Part I: The Superfamily Hedbergelloidea: Revista Española de Micropaleontología, $n^{\circ}$ extraordinario, 61-96.

Longoria, J. F., \& Gamper, M.A. (1984). Subfamily Helvetiellinae, a new group of Late Cretaceous (Maastrichtian) planktonic foraminifera. Micropaleontology, 30(2), 171-179.

Luterbacher, H. P. (1964). Studies in some Globorotalia from the Paleocene and lower Eocene of the central Apennines. Eclogae Geologicae Helvetiae, 57(2), 631-730.

Luterbacher, H. P., \& Premoli-Silva, I. (1964). Biostratigrafia del limite Cretaceo-Terziario nell'Apennino Centrale. Rivista Italiana di Paleontologia e Stratigrafia, 70(1), 67-128.

Maamouri, A. L., \& Salaj, J. (1978). Les Ventilabrellinae et les Pseudotextulariinae, deux nouveaux taxons de la famille des Heterohelicidae Cushman, 1927 emend. Actes du Vle Colloque Africain Micropaléontologie, Tunis-1974, Annales Mines et Géologie, 28(2), 103-109.

Malumián, N., \& Náñez, C. (2011). The Late CretaceousCenozoic transgressions in Patagonia and the Fuegian Andes: foraminifera, palaeoecology, and palaeogeography. Biological Journal of the Linnean Society, 103(2), 269-288. 
Maslakova, N. I. (1964). K sistematike i filogenii Globotrunkanid [On the systematics and phylogeny of the Globotruncanidae]. Voprosy Mikropaleontologii, 8, 102-117. [in Russian]

Maslakova, N. I. (1983). K revizii pozdnemelovykh planktonykh foraminifer semeystva Marginotruncanidae [Revision of Late Cretaceous planktonic foraminifers of the family Marginolruncanidae]. Trudy Instituta Geologii i Geofiziki, Akademiya Nauk SSSR, Sibirskoe otdelenie, 559, 23-31. [in Russian]

McGowran, B. (1964). Foraminiferal evidence for the Paleocene age of the King's Park Shale (Perth Basin, western Australia). Journal of the Royal Society Western Australia, 47(3), 81-88.

Michael, F. Y. (1973). Planktonic foraminifera from the Comanchean Series (Cretaceous) of Texas. Journal of Foraminiferal Research, 2(4), 200-220. doi: 10.2113/ gsjfr.2.4.200

Mikhalevich, V. I. (1980). Sistematika i evolyuciya foraminifer v svete novyikh dannyikh po ih citologii i ul'trastrukture [Systematics and evolution of the Foraminifera in view of the new data on their cytology and ultrastructure]. Trudy Zoologicheskogo Instituta, Akademiya Nauk SSSR, 94, 42-61. [in Russian]

Mohan, M., \& Soodan, K. S. (1967). Inordinatosphaera - a new genus of Globigerinidae. Bulletin of the Geological Society of India, 4(1), 22-25.

Montanaro-Gallitelli, E. (1956). Bronnimannella, Tappanina and Trachilinella, three new foraminiferal genera from the upper Cretaceous. Contributions from the Cushman Foundation for Foraminiferal Research, 7(2), 35-39.

Montanaro-Gallitelli, E. (1957). A revision of the foraminiferal family Heterohelicidae. Bulletin of the United States National Museum, 215, 133-154.

Morard, R., Garet-Delmas, M. J., Mahé, F., Romac, S., Poulain, J., Kucera, M., \& de Vargas, C. (2018). Surface ocean metabarcoding confirms limited diversity in planktonic foraminifera but reveals unknown hyperabundant lineages. Scientific Reports, 8(1), 2539. doi: 10.1038/s41598-018-20833-z

Morozova, V. G. (1957). Nadsemeystvo foraminifer Globigirinideasuperfam. novainekotorye ego predstaviteli [The foraminiferal superfamily Globigerinidea superfam. nova and some of its representatives]. Doklady Akademii Nauk SSSR, 115(5), 1109-1112. [in Russian]

Morozova, V. G. (1959). Stratigrafiya Datsko-Montskikh otlozheniy Kryma po foraminiferam [Stratigraphy of the Danian-Montian deposits of the Crimea according to the foraminifera]. Doklady Akademii Nauk SSSR, 124(5), 1113-1116. [in Russian]

Morozova, V. G., \& Moskalenko, T. A. (1961). Planktonnie foraminiferi progranichnikh otlozhenii Bayosskogo i Batskogo yarusov tsentral'nogo Dagestana (severovostochnii Kavkaz) [Planktonic foraminifera of the boundary strata between Bajocian and Bathonian stages of central Dagestan (northeastern Caucasus)]. Voprosy Mikropaleontologii, 5, 3-30. [in Russian]

Moullade, M., Bellier, J. P., \& Tronchetti, G. (2002). Hierarchy of criteria, evolutionary processes and taxonomic simplification in the classification of Lower Cretaceous planktonic foraminifera. Cretaceous Research, 23(1), 111-148. doi: 10.1006/cres.2002.0304

Nederbragt, A. J. (1989). Maastrichtian Heterohelicidae (Planktonic Foraminifera) from the North West Atlantic.
Journal of Micropaleontology, 8(2), 183-206. doi: 10.1144/jm.8.2.183

Nederbragt, A. J. (1991). Late Cretaceous biostratigraphy and development of Heterohelicidae (planktic foraminifera). Micropaleontology, 37(4), 329-372. doi: $10.2307 / 1485910$

Nederbragt, A. J., Erlich, R. N., Fouke, B. W., \& Ganssen, G. M. (1998). Palaeoecology of the biserial planktonic foraminifer Heterohelix moremani (Cushman) in the late Albian to middle Turonian Circum-North Atlantic. Palaeogeography, Palaeoclimatology, Palaeoecology, 144(1), 115-133. doi: 10.1016/S0031-0182(98)00089-3

Olsson, R. K. (1964). Praeorbulina Olsson, a new foraminiferal genus. Journal of Paleontology, 38(4), 770-771.

Olsson, R. K. (1970). Planktonic foraminifera from base of Tertiary Millers Ferry, Alabama. Journal of Paleontology, 44(4), 598-604. doi: 10.1306/5D25C783-16C1-11D78645000102C1865D

Olsson, R. K., \& Hemleben, Ch. (2006). Chapter 14: Taxonomy, biostratigraphy, and phylogeny of Eocene Globanomalina, Planoglobanomalina n. gen and Pseudohastigerina. In P. N. Pearson, R. K. Olsson, B. T. Huber, Ch. Hemleben, \& W. A. Berggren (Eds.), Atlas of Eocene planktonic foraminifera. Cushman Foundation for Foraminiferal Research, Special Publication, 41, 413-432.

Olsson, H. L., \& Leckie, R. M. (1994). Micropaleontologic proxies for sea-level change and stratigraphic discontinuities. SEPM Society for Sedimentary Geology, Special Publication, 75, 5-19. doi: 10.2110/pec.03.75

Olsson, R. K., Hemleben, Ch., Berggren, W. A., \& Liu, C. (1992). Wall texture classification of planktonic foraminifera genera in the Lower Danian. Journal of Foraminiferal Research, 22(3), 195-213. doi: 10.2113/ gsjfr.22.3.195

Olsson, R. K., Hemleben, Ch., Berggren, W. A., \& Huber, B. T. (Eds.) (1999). Atlas of Paleocene Planktonic Foraminifera. Smithsonian Contributions to Paleobiology, 85, 1-252. doi: 10.5479/si.00810266.85.1

Olsson, R. K., Hemleben, Ch., Huber, B. T., \& Berggren, W. A. (2006a). Chapter 6: Taxonomy, biostratigraphy, and phylogeny of Eocene Globigerina, Globoturborotalita, Subbotina, and Turborotalita. In P. N. Pearson, R. K. Olsson, B. T. Huber, Ch. Hemleben, \& W. A. Berggren (Eds.), Atlas of Eocene planktonic foraminifera. Cushman Foundation for Foraminiferal Research Special Publication, 41, 111-168.

Olsson, R. K., Pearson, P. N., \& Huber, B. T. (2006b). Chapter 5. Taxonomy, biostratigraphy, and phylogeny of Eocene Catapsydrax, Globorotaloides, Guembelitrioides, Paragloborotalia, Parasubbotina, and Pseudoglobigerinella n. gen. In P. N. Pearson, R. K. Olsson, B. T. Huber, Ch. Hemleben, \& W. A. Berggren (Eds.), Atlas of Eocene planktonic foraminifera. Cushman Foundation for Foraminiferal Research Special Publication, 41, 67-110.

Olsson, R. K., Hemleben, Ch., Coxall, H. K. \& Wade, B. S. (2018). Chapter 7: Taxonomy, biostratigraphy, and phylogeny of Oligocene Ciperoella. In B. S. Wade, R. K. Olsson, P. N. Pearson, B. T. Huber, \& W. A. Berggren (2018), Atlas of Oligocene Planktonic Foraminifera. Cushman Foundation Special Publication, 46, 215-230.

Parker, F. L. (1976). Taxonomic notes on some planktonic foraminiferal. In Y. Takayanagi, \& T. Saito (Eds.), Progress in Micropaleontology (pp. 258-262). Special Publication, 
American Museum of Natural History, Micropaleontology Press.

Parker, W. K., \& Jones, T. R. (1872). On the nomenclature of the Foraminifera, Part XV. The species figured by Ehrenberg. Annals and Magazine of Natural History, series 4, 10(57), 184-200.

Parker, W. K., Jones, T. R., \& Brady, H. B. (1865). On the nomenclature of the Foraminifera. Part $X$ (cont.) - The species enumerated by d'Orbigny in the "Annales des Sciences Naturelles". Annals and Magazine of Natural History, serie 3, 16(91), 15-41.

Pearson, P. N., \& Berggren, W. A. (2006). Chapter 10: Taxonomy, biostratigraphy, and phylogeny of Morozovelloides n. gen. In P. N. Pearson, R. K. Olsson, B. T. Huber, Ch. Hemleben, \& W. A. Berggren (Eds.), Atlas of Eocene planktonic foraminifera. Cushman Foundation for Foraminiferal Research Special Publication, 41, 327-342.

Pearson, N. P., Norris, R. D., \& Empson, A. J. (2001). Mutabella mirabilis gen. et sp. nov., a Miocene microperforate planktonic foraminifer with an extreme level of intraspecific variability. Journal of Foraminiferal Research, 31(2), 120132. doi: $10.2113 / 0310120$

Pearson, P. N., Olsson, R. K., Huber, B. T., Hemleben, Ch., \& Berggren, W. A. (Eds.) (2006). Atlas of Eocene planktonic foraminifera. Cushman Foundation for Foraminiferal Research Special Publication.

Pearson, P. N., Wade, B. S., \& Huber, B. T. (2018). Chapter 16: Taxonomy, biostratigraphy, and phylogeny of Oligocene Globigerinitidae (Dipsidripella, Globigerinita, and Tenuitella). In B. S. Wade, R. K. Olsson, P. N. Pearson, B. T. Huber, \& W. A. Berggren (Eds.), Atlas of Oligocene Planktonic Foraminifera. Cushman Foundation Special Publication, 46, 429-458.

Pessagno, Jr., E. A. (1967). Upper Cretaceous planktonic foraminifera from the western Gulf Coastal Plain. Palaeontographica Americana, 5(37), 245-445.

Petters, S. W., El-Nakhal, H. A., \& Cifelli, R. (1983). Costellagerina, a new Late Cretaceous globigerine foraminiferal genus. Journal of Foraminiferal Research, 13(4), 247-251. doi: 10.2113/gsjfr.13.4.247

Poag, C. W. (1989). Foraminiferal stratigraphy and paleoenvironments of Cenozoic strata cored Near Haynesville, Virginia. In R. B. Mixon (Ed.), Geology and paleontology of the Haynesville Cores Northeastern Virginia Coastal Plain. United States Geological Survey Professional Paper, 1489, D1-D20.

Poag, C. W. (2012). Foraminiferal repopulation of the Late Eocene Chesapeake Bay Impact Crater. Micropaleontology, 58(1-2), 1-206.

Pokorný, V. (1955). Cassigerinella boudecensis n. gen., n. sp. (Foraminifera, Protozoa) z oligocénu ždánického flyše [Cassigerinella boudecensis n. gen., n. sp. (Foraminifera, Protozoa) from the Oligocene of the Ždánice flysch]. Vestnik Ustredního Ústavu Geologického, 30, 136-140. [in Czech]

Pokorný, V. (1958). Grundzügge der Zoologischen Mikropaläeontologie. Band 1, VEB Deutscher Verlag de Wissenschaften.

Popescu, G. (1969). Some new Globigerina (Foraminifera) from the Upper Tortonian of the Transylvanian basin and the Subcarpathians. Revue Roumaine de Géologie, Géophysique et Géographie, Série de Géologie, 13, 103106.

Popescu, G. (1987). Marine Middle Miocene microbiostratigraphical correlation in Central Paratethys. Dări de
Seamă ale Şedinţelor Institutul de Geologie și Geozică, 72-73(3), 149-167.

Postuma, J. A. (1971). Manual of planktonic Foraminifera. Elsevier Publishing Co.

Premoli-Silva, I., Caron, M., Leckie, R. M., Petrizzo, M. R., Soldan, D., \& Verga, D. (2009). Paraticinella n. gen. and taxonomic revision of Ticinella bejaouaensis Sigal, 1966. Journal of Foraminiferal Research, 39(2), 126-137. doi: 10.2113/gsjfr.39.2.126

Reichel, M. (1950). Observations sur les Globotruncana du grisement de la Breggia (Tessin). Ecoglae geologicae Helvetiae, 42, 596-617.

Reiss, Z. (1957). The Bilamellidea nov. superfam., and remarks on Cretaceous globorotaliids. Contributions from the Cushman Foundation for Foraminiferal Research, 8(4), 127-145.

Reiss, Z. (1963). Reclassification of perforate foraminifera. Bulletin of the Geological Survey of Israel, 35, 1-111.

Resig, J. M., \& Kroopnick, P. M. (1983). Isotopic and distributional evidence of a planktonic habit for the foraminiferal genus Streptochilus Brönnimann and Resig, 1971. Marine Micropaleontology, 8(3), 235-248. doi: 10.1594/PANGAEA.682292

Reuss, A. E. (1860). Die Foraminiferen der westphälischen Kreideformation. Sitzungsberichte der mathematischnaturwissenschaflichen Classe der kaiserlichen Akademie der Wissenschaften, 40(8), 147-238.

Robaszynski, F., \& Caron, M. (1979). Atlas of mid Cretaceous planktonic foraminifera (Boreal sea and Tethys). Cahiers de Micropaléontologie, 1, 1-185, 2, 1-181.

Robaszynski, F., Caron, M., González-Donoso, J. M., \& Wonders, A. A. H. (1984). Atlas of Late Cretaceous Globotruncanids. Revue de Micropaléontologie, 26(3-4), 145-305.

Rzehak, A. (1891). Die Foraminiferen-Fauna der alttertiiiren Ablagerungen von Brunderndorf in Niederosterreich, mit Berücksichtigung des angeblichen Kreidevorkommens von Leitzersdorf. Annalen des Naturhistorischen Hofmuseum, Wien, 6(1), 1-12.

Saito, T., Thompson, P. R., \& Breger, D. (1976). Skeletal ultramicrostructure of some elongate-chambered planktonic foraminifera and related species. In Y. Takayanagi, \& T. Saito (Eds.), Progress in Micropaleontology (pp. 278-304). American Museum of Natural History Micropaleontology Press.

Saito, T., Thompson, P. R., \& Breger, D. (1981). Systematic Index of Recent and Pleistocene Planktonic Foraminifera. University of Tokyo Press.

Salaj, J. 1986. The new Postrugoglobigerina praedaubjergensis Zone at the base of the stratotype of the marine Paleocene (El Kef, Tunisia). Geologicky Zbornik, Geologica Carpathica Bratislava, 37, 35-58.

Salaj, J., \& Maamouri, A. L. (1984). Campanian/Maastrichtian boundary in Tunisia. Geologicky Zbornik, Geologica Carpathica Bratislava, 35, 551-558.

Salaj, J., \& Solakius, N. (1984). The genus Kassabiana Salaj, 1983, from the uppermost Maastrichtian of northeastern Tunisia. Canadian Journal of Earth Sciences, 21(10), 1199-1204. doi: 10.1139/e84-125

Schultze, M. (1854). Ueber den Organismus der Polythalamien (Foraminiferen) nebst Bermerkungen über die Rhizopoden im allgemeinen. Verlag von Wilhelm Engelmann.

Schwager, C. (1866). Fossile Foraminiferen von Kar Nikobar. Reise der Österreichischen Fregatte Novara 
um die Erde in den Jahren 1857, 1858, 1859 unter den Befehlen des Commodore B. von Wüllerstorf-Urbair. Geologischer Theil (Zweite Abtheilung, Paläontologische Mittheilungen), 2(2), 187-268.

Sen-Gupta, B. K., \& Machain-Castillo, M. L. (1993). Benthic foraminifera in oxygen poor habitats. Marine Micropaleontology, 20(3-4), 183-201. doi: 10.1016/03778398(93)90032-S

Sigal, J. (1948). Notes sur les genres de foraminifères Rotalipora Brotzen 1942 et Thalmanninella; famille des Globorotaliidae. Revue de I'Institut Francais des Combustibles Liquides (du Petrole), 3(4), 95-103.

Sigal, J. (1956). Notes micropaléontologiques nordafricaines. 4. Biticinella breggiensis (Gandolfi), nouveau morphogenre. Comptes Rendu Sommaire des Séances de la Société Géologique de France, 1956, 35-36.

Sigal, J. (1958). La classification actuelle des familles de foraminifères planktoniques du Crétacé. Comptes Rendu Sommaire des Séances de la Société Géologique de France, 1958, 262-265.

Smart, C. W., \& Thomas, E. (2007). Emendation of the genus Streptochilus Brönnimann and Resig 1971 (Foraminifera) and new species from the lower Miocene of the Atlantic and Indian Oceans. Micropaleontology, 53(1-2), 73-103. doi: 10.2113/gsmicropal.53.1-2.73

Smart, C. W., \& Thomas, E. (2018). Chapter 19: Taxonomy, biostratigraphy, and phylogeny of Oligocene Streptochilus. In B. S. Wade, R. K. Olsson, P. N. Pearson, B. T. Huber, \& W. A. Berggren (Eds.), Atlas of Oligocene Planktonic Foraminifera. Cushman Foundation Special Publication, 46, 495-510.

Smit, J. (1982). Extinction and evolution of planktonic foraminifera after a major impact at the Cretaceous/ Tertiary boundary. Geological Society of America Special Papers, 190, 329-352. doi: 10.1130/SPE190-p329

Smith, C. C., \& Pessagno, Jr., E. A. (1973). Planktonic Foraminifera and Stratigraphy of the Corsicana Formation (Maastrichtian) North-central Texas. Cushman Foundation for Foraminiferal Research, Special Publication, 12, 1-67.

Soldan, D. M., Petrizzo, M. R., \& Premoli-Silva, I. (2014). Pearsonites, a new paleogene planktonic foraminiferal genus for the broedermanni lineage. Journal of Foraminiferal Research, 44(1), 17-27. doi: 10.2113/ gsjfr.44.1.17

Soldan, D. M., Petrizzo, M. R., \& Premoli-Silva, I. (2018). Alicantina, a new Eocene planktonic foraminiferal genus for the lozanoi group. Journal of Foraminiferal Research, 48(1), 41-52. doi: 10.2113/gsjfr.48.1.41

Spezzaferri, S., Kucera, M., Pearson, P. N., Wade, B. S., Rappo, S., Poole, C. R., Morard, R., \& Stalder, C. (2015). Fossil and genetic evidence for the polyphyletic nature of the planktonic foraminifera "Globigerinoides", and description of the new genus Trilobatus. PLOS ONE, 10(5), e0128108. doi: 10.1371/journal.pone.0128108

Spezzaferri, S., Coxal, H. K., Olsson, R. K., \& Hemleben, Ch. (2018). Taxonomy, biostratigraphy, and phylogeny of Oligocene Globigerina, Globigerinella, and Quiltyella n. gen. In B. S. Wade, R. K. Olsson, P. N. Pearson, B. T. Huber, \& W. A. Berggren (Eds.), Atlas of Oligocene Planktonic Foraminifera. Cushman Foundation for Foraminiferal Research, Special Publication, 46, 179214.

Stainforth, R. M., Lamb, J. L., Luterbacher, H. P., Beardand, J. H., \& Jeffords, R. M. (1975). Cenozoic planktonic foraminiferal zonation and characteristics of index form. Paleontological Contributions, 62, 425 pp.

Stolk, J. (1965). Contribution é l'étude des correlations microfauniques du Tertiaire inférieur de la Nigeria méridionale. Memoires du Bureau de Recherches Géologiques et Miniéres, 32, 247-275.

Subbotina, N. N. (1953). Iskopaemye Foraminifery SSSR Globigerinidy, Khantkeninidy i Globorotaliidy [Fossil Foraminifera of the USSR. Globigerinidae, Hantkeninidae and Globorotaliidae]. Trudy Vsesoyuznogo Neftyanogo Nauchno-issledovarel'skogo Geologo-razwdochnogo Instituta (VNIGRI), 76, 1-296. [in Russian]

Subbotina, N. N. (1959). Planktonic foraminifera. In D. M. Rauzer-Chernousova, \& A. V. Fursenko (Eds.), Principles of paleontology, part 1, Protozoa (pp. 1-368). Akademia Nauk SSSR.

Subbotina, N. N. (1971). Sistematika Kaynozoyskikh planktonnykh foraminifer [Systematics of Cenozoic planktonic foraminifera]. Trudy Vsesoyuznogo Neftyanogo Nauchno-issledovarel'skogo Geologorazwdochnogo Instituta (VNIGRI), 291, 63-69. [in Russian]

Šulc, J. (1929). Příspěvky k poznání morfológie foraminifer [Contribution to knowledge of foraminifer morphology]. Věstník Štátního geologického ústavu Českoslpvenské Republiky, 5, 148-155. [in Czech]

Tappan, H. (1940). Foraminifera from the Grayson Formation of northern Texas. Journal of Paleontology, 14(2), 93-126.

Tappan, H., \& Loeblich, Jr., A. R. (1988). Foraminiferal evolution, diversification and extinction. Journal of Paleontology, 62, 695-714.

Thalmann, H. E. (1932). Die foraminiferen-Gattung Hantkenina Cushman, 1924, und ihre regionalstratigraphische Verbreitung. Eclogae geologicae Helvetiae, 25, 287-292.

Thalmann, H. E. (1942). Foraminiferal genus Hantkenina and its subgenera. American Journal of Science, 240(11), 809-820. doi: 10.2475/ajs.240.11.809

Thompson, P. R. (1973). Two new late Pleistocene Foraminifera from a core in the southwest Indian Ocean. Micropaleontology, 19(4), 469-474.

Thomson, W. (1876). Comments. In J. Murray, (Ed.), Preliminary reports to Professor Wyville Thomson, F.R.S., director of the civilian scientific staff, on work done aboard the "Challenger". Proceedings of the Royal Society of London, 24, 471-544.

Toumarkine, M., \& Luterbacher, H. P. (1985). Paleocene and Eocene planktic foraminifera. In H. M. Bolli, J. B. Saunders, \& K. Perch-Nielsen (Eds.), Plankton Stratigraphy (pp. 87-154). Cambridge University Press.

Turnovsky, K. (1958). Eine neue Art von Globorotalia Cushman ans dem Eozaen Anatoliens und ihre Zuordnung zu einer neuen Untergattung. Bulletin of the Geological Society of Turkey, 6(2), 80-86.

Ujiié, H. (1976). Prosphaeroidinella, n. gen.: Probable ancestral taxon of Sphaeroidinellopsis (Foraminifera). Bulletin of the National Science Museum, Tokyo, Series C (Geology \& Paleontology), 2(1), 9-26.

Ujiié, Y., \& Lipps, J. H. (2009). Cryptic diversity in planktonic foraminifera in the northwest Pacific Ocean. Journal of Foraminiferal Research, 39(3), 145-154. doi: 10.2113/ gsjfr.39.3.145

Ujiié, Y., Kimoto, K., \& Pawlowski, J. (2008). Molecular evidence for an independent origin of modern triserial 
planktonic foraminifera from benthic ancestors. Marine Micropaleontology, 69(3), 334-340. doi: 10.1016/j. marmicro.2008.09.003

Verga, D., \& Premoli-Silva, I. (2005). Early Cretaceous planktonic foraminifera from the Tethys: the Upper Aptian, planispiral morphotypes with elongate chambers. Cretaceous Research, 26(2), 239-259., doi: 10.1016/j. cretres.2005.01.004

Von Hillebrandt, A. (2012). Are the Late Triassic to Early Jurassic aragonitic Oberhauserellidae (Robertinina) the ancestors of planktonic Foraminifera? Neues Jahrbuch für Geologie and Paläontologie, Abhundlungen, 266(3), 199-215. doi: 10.1127/0077-7749/2012/0279

Wade, B. S., Olsson, R. K., Pearson, P. N., Huber, B. T., \& Berggren, W. A. (Eds.) (2018). Atlas of Oligocene Planktonic Foraminifera. Cushman Foundation Special Publication.

Wernli, R. (1988). Les protoglobigérines (foraminifères) du Toarcien et de l'Aalénien du Donuz Dag (Taurus occidental, Turquie). Eclogae geologicae Helvetiae, 81(3), 661-668. doi: 10.5169/seals-166198
Wernli, R. (1995). Les foraminifères globigériniformes (Oberhauserellidae) du Toarcien inférieur de Teysachaux (Préalpes medianes, Fribourg, Suisse). Revue de Paléobiologie, 14(2), 257-269.

Wernli, R., \& Görög, A. (2007). Protoglobigerinids and Oberhauserellidae (Foraminifera) of the BajocianBathonian of the Southern Jura Mts, France. Revue de Micropaléontologie, 50(2), 185-205. doi: 10.1016/j. revmic.2006.11.001

Williamson, W. C. (1858). On the recent Foraminifera of Great Britain. The Ray Society.

Wonders, A. A. H. (1978). Phylogeny, classification and biostratigraphic distribution of keeled Rotaliporinae (II). Proceedings of the Koninklijke Nederlandse Akademie van Wetenschappen, Amsterdam, Series B, 81(1), 125144.

Young, J. R., Wade, B. S., \& Huber, B. T. (2017).pforams@ mikrotax website. http://www.mikrotax.org/pforams [July 2021]

Zhang, J., \& Scott, D. B. (1995). New Planktonic Foraminiferal Genus and Species from the Upper Oligocene, DSDP Hole 366A, Leg 41. Micropaleontology, 41(1), 77-83. 